February 2016

\title{
Asymmetric Credit Growth and Current Account Imbalances in the Euro Area
}

\author{
Robert Unger ${ }^{1}$
}

\begin{abstract}
The euro area crisis is often linked to the emergence of current account imbalances. As most of the deficit countries experienced pronounced credit booms at the same time that these imbalances were building up, this paper investigates the link between domestic credit developments and the current account balance. Using a panel error correction specification, the estimation results show that flows of bank loans to the non-financial private sector are a significant determinant of the current account and that they - together with changes in competitiveness - constituted the most important factor driving the build-up of current account imbalances in the deficit countries. Accordingly, impeding an increase in private sector indebtedness seems to be a promising way to dampen the formation of unsustainable current account imbalances.
\end{abstract}

JEL:

E50, F32, F45, G21

Keywords: banks, credit growth, current account imbalances, euro area

1 Deutsche Bundesbank, Wilhelm-Epstein-Straße 14, 60431 Frankfurt am Main, Germany. Phone: +49 699566 7409. E-mail: robert.unger@bundesbank.de. This is a slightly revised version of Bundesbank Discussion Paper No $36 / 2015$. 



\title{
Asymmetric Credit Growth and Current Account Imbalances in the Euro Area*
}

\author{
Robert Unger (Deutsche Bundesbank)
}

February 2016

\begin{abstract}
The euro area crisis is often linked to the emergence of current account imbalances. As most of the deficit countries experienced pronounced credit booms at the same time that these imbalances were building up, this paper investigates the link between domestic credit developments and the current account balance. Using a panel error correction specification, the estimation results show that flows of bank loans to the non-financial private sector are a significant determinant of the current account and that they - together with changes in competitiveness - constituted the most important factor driving the build-up of current account imbalances in the deficit countries. Accordingly, impeding an increase in private sector indebtedness seems to be a promising way to dampen the formation of unsustainable current account imbalances.
\end{abstract}

Keywords: banks, credit growth, current account imbalances, euro area

JEL classification: E50, F32, F45, G21.

\footnotetext{
${ }^{*}$ Contact address: Deutsche Bundesbank, Wilhelm-Epstein-Straße 14, 60431 Frankfurt am Main, Germany. Phone: +49699566 7409. E-mail: robert.unger@bundesbank.de. This is a slightly revised version of Bundesbank Discussion Paper No 36/2015. The views presented in this paper are the author's personal opinion and do not necessarily represent the views of Deutsche Bundesbank or the Eurosystem. I would like to thank an anonymous referee, Jörg Breitung, Mariarosaria Comunale, Michael Frenkel, Rafael Gerke, Axel Jochem, Stephan Kohns, Jochen Mankart, Michael Massmann, Ian McLoughlin, Martin Micheli, Manuel Rupprecht, Hanno Stremmel, Andreas Worms, seminar participants at the Deutsche Bundesbank and at WHU Vallendar, participants at the European Economic and Finance Society 2015 Conference in Brussels, at the Macroeconomics Workshop "The Euro Crisis: Where Do We Stand?" in Strasbourg and at the 8th FIW-Research Conference "International Economics" in Vienna for their helpful comments and suggestions. Any errors or omissions are the responsibility of the author.
} 


\section{Introduction}

The euro-area crisis is often linked to the emergence of current account imbalances. When capital inflows receded, the deficit countries started to undergo a far-reaching adjustment process that was accompanied by severe negative repercussions for the real economy and the banking system. As a consequence, identifying the deeper causes of the current account imbalances that led to the crisis has been high on the policy agenda.

Up to the outbreak of the crisis, current account deficits were perceived as the result of a welcome catch-up process of lower-income countries (see, for example, Blanchard and Giavazzi, 2002; Campa and Gavilan, 2011; Schmitz and von Hagen, 2011). Research in immediate response to the crisis identified competitiveness and fiscal imbalances as the main causes (see, for example, Arghyrou and Chortareas, 2008; Belke and Dreger, 2013; Schnabl and Wollmershäuser, 2013). More recently, attention has shifted to domestic demand and financial factors as the main drivers of current account imbalances.

Since the Eurosystem's interest rate policy is directed at the euro-area average, EMU countries were characterized by widely diverging monetary policy conditions (see, for example, Ahrend, 2010). Building on a modified version of the Walters (1990) critique, Wyplosz (2013) argues that, in countries where monetary policy was too loose, domestic demand boomed and led to a deterioration of the current account. The loss of competitiveness was then a mere reflection of the increase in demand, not the cause of the current account imbalances. Comunale and Hessel (2014) apply this idea to the data and show that domestic demand fluctuations at the frequency of the financial cycle are the main driver of current account dynamics, whereas changes in competitiveness play only a minor role.

I link these contributions to the literature on the relation between domestic and external debt dynamics. Lane and McQuade (2014) find that domestic credit growth is driven by net debt inflows. However, this result is less clear-cut when net debt flows are instrumented to address potential endogeneity concerns. Based on a cointegration analysis, Cuestas and Staehr (2014) show that domestic credit error corrects deviations from its long-run relation with net foreign liabilities in Greece and Italy, whereas the relation is bicausal in Spain and Portugal. Using Granger causality tests, Kool, de Regt, and van Veen (2013) find significant bidirectional causality between net external debt flows and measures of domestic money and credit overhangs.

Whereas the empirical literature so far has failed to establish a clear direction of causality between domestic and external credit, there is considerable evidence that the current accounts of the deficit countries were ultimately financed by banks in the surplus countries (see, for example, Spiegel, 2009; Lane, 2013; Hobza and Zeugner, 2014). The most commonly found theoretical presumption regarding causality is that inflows of external credit drive domestic credit growth, which then leads to a current account deficit when funds are spent on imports. ${ }^{1}$ One main drawback of this line of reasoning is that it fails to take account of the institutional fact that banks create new purchasing power in the form of deposits when they grant loans (see, for example, Borio and Disyatat, 2010,

\footnotetext{
${ }^{1}$ Against this theoretical presumption, Zwick (2015), building on Hristov, Hülsewig, and Wollmershäuser (2012), provides empirical evidence that an adverse international liquidity shock does not significantly reduce lending to the private non-financial sector provided by domestic banks
} 
2011; Disyatat, 2011; McLeay, Radia, and Thomas, 2014; Jakab and Kumhof, 2015). ${ }^{2}$

Seen from this perspective, the causal chain starts with credit creation at the level of the domestic banking sector. When the newly created deposits are spent on imports, this leads to a current account deficit. To recover the reserves lost in the process of payment settlement, the banking system in the deficit country has to refinance with banks in the surplus countries, who were, at least in the boom years, willing to lend their excess reserves back to the banks in the deficit countries. ${ }^{3}$ The end result of these flows is that the loan extended by a bank in the deficit country is ultimately financed by a bank in the surplus country, which in turn incurs a liability against the depositor that sold the export good. ${ }^{4}$ Note that it is the specific institutional setup of the euro-area banking system that enables banks in one country of the currency area to create deposits that can be used to purchase imports from other euro area countries. Accordingly, this theoretical reasoning regarding the causality between domestic and external credit flows cannot necessarily be generalized. ${ }^{5}$

Against this background, the paper analyzes the impact of credit growth on the current account balance of euro-area countries. I distinguish two principal ways in which credit growth can be linked to the current account and which can be thought of as potential points of policy intervention. On the one hand, in countries where the Eurosystem's common monetary policy has a comparatively more expansionary effect, the domestic non-financial private sector should increase its liabilities. This can operate as a pull factor which increases domestic demand, draws in additional imports, and leads to a deterioration of the current account. On the other hand, in countries where the common monetary policy has a comparatively more restrictive effect, domestic banks should shift savings abroad by increasing their claims on external debtors. This can work as a push factor which is associated with an improvement in the current account.

The impact of these two factors is estimated in a panel with annual observations for the period from 1999 to 2013 for the euro-area founding members and Greece, controlling for the impact of the determinants most commonly found in the existing literature on euro-area imbalances - a catch-up variable, a proxy for competitiveness and the fiscal balance - as well as variables found in the broader literature on current account determinants (see, for example, Chinn and Prasad, 2003; Barnes, Lawson, and Radziwill, 2010; CaZorzi, Chudik, and Dieppe, 2012; Lane and Milesi-Ferretti, 2012). Since a variety of tests suggest that the data are non-stationary and cointegrated, I estimate panel error correction models, as is now commonly done in the literature on current account determinants (see, for example, Smith, 2011; Belke and Dreger, 2013; Gossé and Serranito, 2014).

The main results are the following: The proxy for the credit pull factor (flows of bank

\footnotetext{
${ }^{2}$ See Moore (1988) for an earlier treatment.

${ }^{3}$ When banks in the surplus countries started to cut lending to banks in the deficit countries, the latter strongly increased their refinancing operations with the Eurosystem. The resulting payment flows were then reflected in the (in)famous TARGET2 balances.

${ }^{4}$ As a consequence of this, the net foreign asset position of the banking sector might replace bank credit as the main driver of money growth in the surplus countries. See Kuzin and Schobert (2015) for evidence for Germany.

${ }^{5}$ For example, banks in Central and Eastern Europe were dependent on the prior provision of credit by banks in the euro area to finance their countries' current account deficits, i.e. inflows of external credit boosted the (foreign currency) lending capacities of local banks.
} 
loans to the domestic non-financial private sector) is significant in all models. The measure for the credit push factor (flows of claims of domestic banks on debtors in other euro-area countries) is significant in only some specifications, and the coefficient is much smaller than the one for the credit pull factor. Based on the coefficient estimates I also show that the build-up of current account imbalances before the crisis as well as their subsequent correction in the deficit countries over the past few years were to a large extent driven by variations in flows of bank loans to the domestic non-financial private sector.

The rest of the paper is structured as follows. Section 2 describes the data set and the empirical strategy. Section 3 discusses the results. Finally, section 4 summarizes the findings and draws policy conclusions.

\section{Data and empirical strategy}

\subsection{Data set}

The panel consists of the founding members of the euro area and Greece. Luxembourg has to be omitted due to lacking data. ${ }^{6}$ Data are available at a yearly frequency over the period from 1999 to 2013. In total, there are 165 observations. The choice of countries and time period is mainly driven by data availability. Most importantly, the data for the variables of primary interest - the credit pull and push factors - are only available from 1999 onwards. As the current account imbalances are mainly an intra-euro-area phenomenon the country selection is restricted to members of the single currency. As a result of this choice, a rather homogeneous panel is created allowing the application of a more efficient estimator.

Since no ready-made variables exist for the credit push and pull factors, they have to be constructed. As it is a priori unclear which type of liabilities and claims should be used, I calculate a variety of proxies. The main data sources are the Quarterly Euro Area Accounts for the credit pull factor as well as the MFI Balance Sheet Items for the credit push factor, as provided by the ECB's Statistical Data Warehouse. All variables are measured as flows (i.e. the net acquisition of financial assets or the net incurrence of liabilities) as a percentage of nominal GDP. Table 3 in the appendix provides a detailed description of the underlying time series.

The credit pull factor always measures liabilities of the domestic non-financial private sector (i.e. non-financial corporations and private households). In total, five different measures are constructed. The all-encompassing proxy LIABILITIES captures total liabilities towards all sectors as classified in the financial accounts. It includes a broad set of instruments, such as equity, debt securities and loans. A bit more narrowly defined is the measure $D E B T$ which comprises only debt securities and loans. The proxy $L O A N S$ includes loans from all creditors. The measure BANKLOANS is narrowed down to all loans granted by domestic banks. The tightest proxy is labeled REALBANKLOANS and contains all loans granted by domestic banks excluding loans for house purchase. The construction of the last variable is motivated by the idea that loans granted for the purchase of real estate will not have an immediate impact on domestic demand, as the

\footnotetext{
${ }^{6}$ Accordingly, the panel consists of the following countries: Austria, Belgium, Germany, Finland, France, Greece, Ireland, Italy, Netherlands, Portugal and Spain.
} 
funds are spent on an existing asset (the house). ${ }^{7}$ Irrespective of which proxy is used, an increase in the credit pull factor is expected to lead to a deterioration of the current account. Accordingly, the expected sign is negative.

The credit push factor always measures external debt claims of domestic banks. In total, five different measures are constructed. The broadest proxy includes claims of domestic banks on debtors in euro-area countries other than the home country in the form of debt securities and loans and is denoted BANKCLAIMS. The measure INTERBANKCLAIMS encompasses only the debt claims of domestic banks on banks in the rest of the euro area. Both proxies are also measured on a net basis by deducting domestic banks' liabilities in the form of loans towards creditors in euro-area countries other than the home country and labeled NETBANKCLAIMS and NETINTERBANKCLAIMS. ${ }^{8}$ Finally, NETINTERBANKLOANS measures the net claims of domestic banks on banks in other euro-area countries in the form of loans. Irrespective of which proxy is used, an increase in the credit push factor is presumed to lead to an improvement in the current account. Accordingly, the expected relation with the current account is positive.

Figure 1 below shows time series for, respectively, the most broadly and most narrowly defined credit pull and push factors. To condense information, the graphs show unweighted averages for the deficit countries (Greece, Ireland, Italy, Portugal and Spain), surplus countries (Austria, Germany and Netherlands) and other countries (Belgium, Finland and France). ${ }^{9}$ Table 7 in the appendix provides descriptive statistics. As expected, both credit pull factors show higher values for the deficit countries compared to the ones for the surplus countries for the boom period, implying that countries in which the nonfinancial private sector increased its liabilities more strongly were tending to run a current account deficit and vice versa. Beginning with the Global Financial Crisis credit flows in the deficit countries started to collapse and turned negative. For the credit push factors, the picture is less clear-cut. Theoretically, the time series for the surplus countries should have higher values than the ones for the deficit countries. However, this is only the case for the most narrowly defined proxy NETINTERBANKLOANS. Upon closer inspection, one finds that this counterintuitive result is driven by the inclusion of Ireland in the group of deficit countries. As the country is a financial center with a lot of cross-border banking, the values are biased upwards. If Ireland is excluded, the values for the most broadly defined credit push factor BANKCLAIMS for the deficit countries are also below those for the surplus countries.

\footnotetext{
${ }^{7}$ See Werner (1997) for a theoretical derivation of this idea. As the funds obtained from loans for house purchase can also be spent on newly build houses, this proxy is rather crude, but, nevertheless, the best estimate that can be obtained given data availability.

${ }^{8}$ Ideally, one should also deduct liabilities in the form of debt securities of domestic banks. However, as the MFI Balance Sheet Items lack counterpart information for this instrument, its is not possible to perform this calculation.

${ }^{9}$ Even though Italy did not have persistently high current account deficits, it is included in the group of deficit countries as it also fell victim to the crisis.
} 

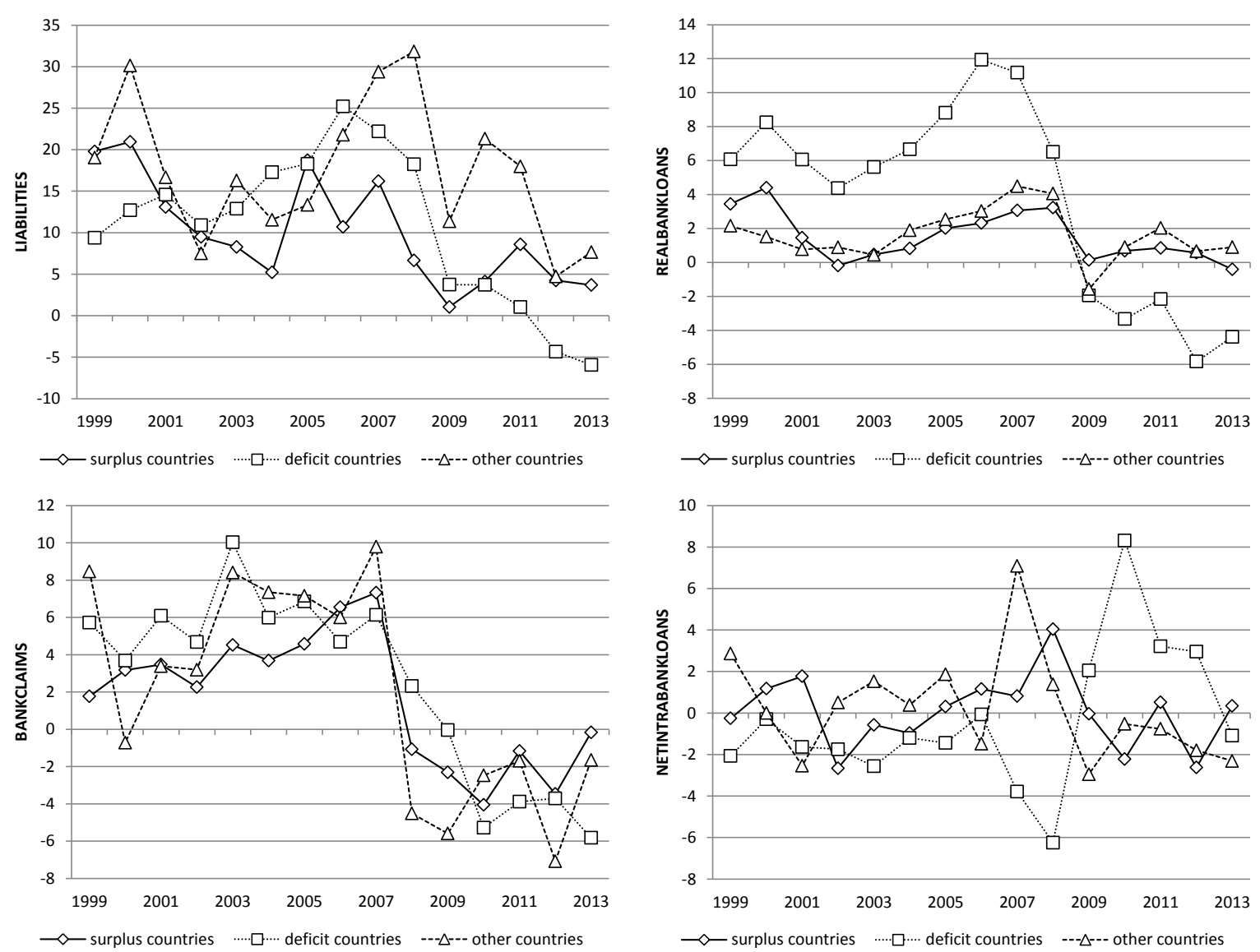

Figure 1: Time series for credit push and pull factors (Notes: The graphs show unweighted averages for the respective country groups. Deficit countries are Greece, Ireland, Italy, Portugal and Spain. Surplus countries are Austria, Germany and Netherlands. Other countries are Belgium, Finland and France.)

The dependent variable current account balance is measured as a percentage of nominal GDP and labeled $C A$. The catch-up variable is constructed by dividing real GDP per capita based on purchasing power standard of the respective country by the value for the euro-area 12 aggregate and denoted RELATIVEGDP. The intertemporal approach to international macroeconomics suggests that low-income countries should have a high marginal product of capital. As investment opportunities exceed domestic savings, this should lead to a current account deficit and, accordingly, a negative relation is expected. As the competitiveness proxy, the real harmonised competitiveness indicator deflated by unit labor costs (ULC) in total economy is used. As unit labor costs reflect both productivity trends and (lagged) wage developments, this proxy is less likely to cause endogeneity problems than alternative competitiveness indicators such as those based on price deflators. To take account of the relative nature of competitiveness, the values for the respective countries are likewise divided by the figure for the euro-area 12 aggregate. ${ }^{10}$ The resulting variable is labeled $R E A L E X R U L C$. A higher value of the indicator im-

\footnotetext{
${ }^{10}$ By dividing the respective country value by the figure for the euro-area 12 aggregate the nominal exchange rate is effectively removed, further reducing potential endogeneity problems that the inclusion of the exchange rate might cause.
} 
plies lower competitiveness and should lead to a deterioration of the current account. Accordingly, a negative sign is expected. The fiscal balance is measured as a percentage of GDP and denoted GOVBALANCE. According to the twin-deficit hypothesis, a fiscal deficit results in a current account deficit and the expected relation is therefore positive. Figure 2 below shows time series for the independent variable and the main controls for the three country groups.
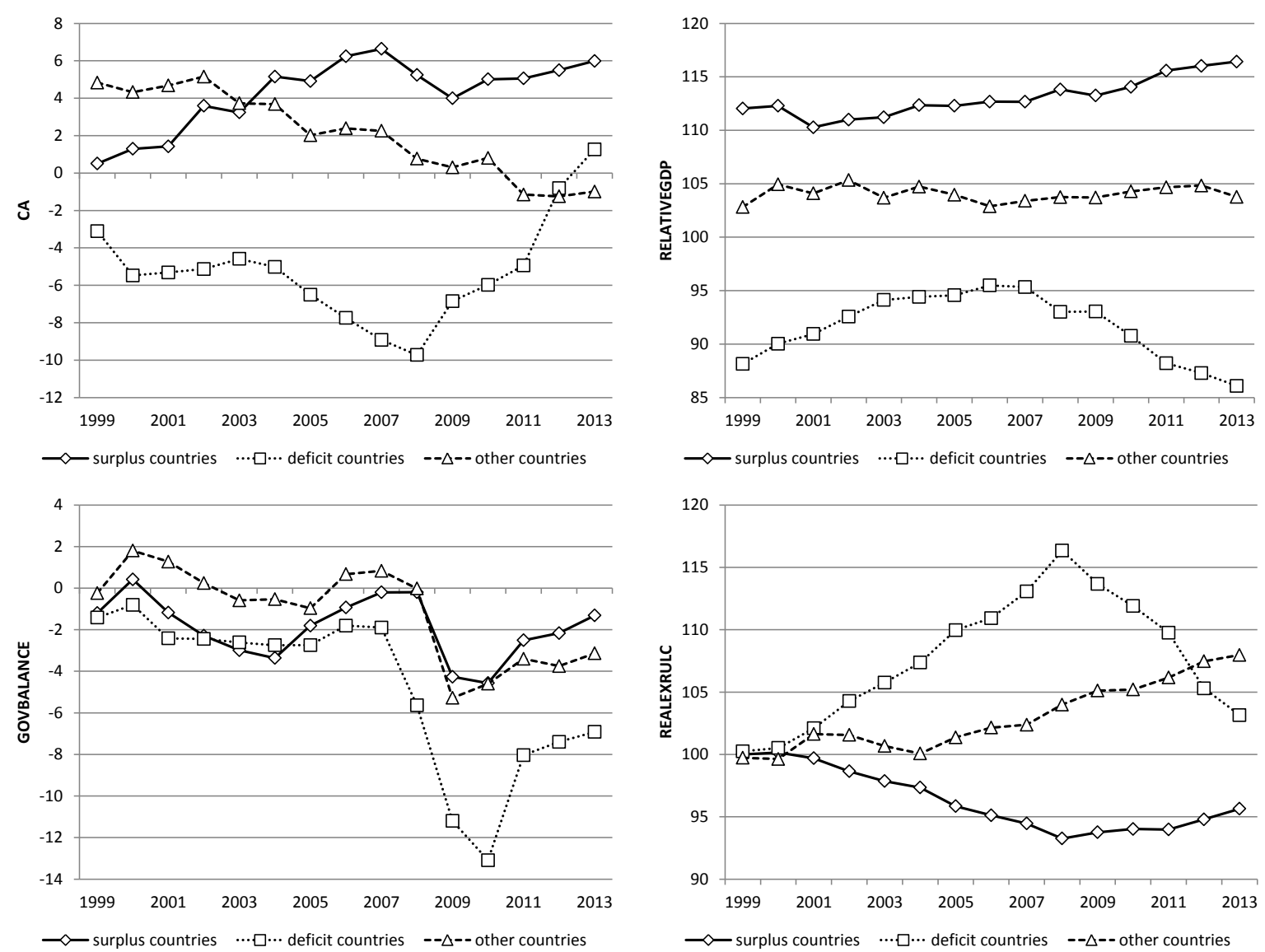

Figure 2: Time series for the current account balance and the main control variables (Notes: The graphs show unweighted averages for the respective country groups. Deficit countries are Greece, Ireland, Italy, Portugal and Spain. Surplus countries are Austria, Germany and Netherlands. Other countries are Belgium, Finland and France.)

To improve the robustness of the results, I also control for the influence of variables used in the broader literature on current account determinants (see, for example, Chinn and Prasad, 2003; Barnes et al., 2010; CaZorzi et al., 2012; Lane and Milesi-Ferretti, 2012). The dependency ratio measures the percentage of people younger than 15 or older than 64 in the working-age population and is denoted DEPENDENCY. As the working-age population should have a higher savings ratio than the dependent part of the population, a negative relation with the current account is expected. The population growth rate is the year-on-year growth rate of the population and labeled POPULATION. As a fast-growing population supposedly has a higher need for investment, the expected sign is negative. The net international investment position is the difference between foreign assets and liabilities. To reflect the fact that the position is measured as the amount 
outstanding at the end of the year, the variable is lagged by one period and denoted $N F A_{t-1}$. A positive balance should generate a positive investment income and improve the current account. Accordingly, a positive connection is expected.

The government bond yield deflated by the Harmonized Index of Consumer Prices (HICP) serves as a proxy for the long-term interest rate and is denoted INTEREST. A high interest rate should encourage saving and reduce investment, both of which implies an improvement in the current account. Accordingly, a positive sign is expected. Finally, the real house price growth rate is measured by the year-on-year change in the respective house price index deflated by the HICP and labeled HOUSEPRICE. Rising house prices generate a wealth effect and should induce households to reduce their savings. At the same time, they make property investment attractive and should lead to higher residential investment and capital inflows. Both factors imply a worsening of the current account and, consequently, a negative relation between the two variables is expected. ${ }^{11}$ Details on the data sources are provided in Table 3 in the appendix.

\section{$2.2 \quad$ Empirical strategy}

As earlier research finds that many of the time series seem to be non-stationary, I run various unit root tests to check the properties of the data. More specifically, the ImPesaran-Shin test, Pesaran's CADF test and a test developed by Breitung, are calculated. The results can be summarized as follows (see Tables 4 and 5 in the appendix for details). For the current account balance as well as the proxy for competitiveness and the fiscal balance, the tests almost unanimously indicate that the variables are integrated of order one. The results for the credit push and pull factors are mixed. Whereas the tests hint at unit roots for the proxies DEBT, LOANS, BANKLOANS and REALBANKLOANS, the remaining measures seem to be rather stationary. Regarding the additional control variables, there are clear indications of non-stationarity for the population growth rate. For the catch-up variable, the dependency ratio, the net international investment position, the long-term interest rate and the house price growth rate, the results are mixed.

I then proceed to estimate whether the variables cointegrate. Given their good finitesample properties, the Kao test and Pedroni's ADF and PP tests are applied. The tests confirm that the current account balance cointegrates with its determinants. A long-term relation can already be found in the reference model including the catch-up variable, the proxy for competitiveness and the fiscal balance. Most of the time, the results become even stronger when the credit push and pull factors as well as the additional control variables are included (see Table 6 in the appendix for details). ${ }^{12}$ Bearing the considerable estimation uncertainty regarding the unit root and cointegration tests in mind, I presume for the main estimations that the variables are non-stationary and cointegrated. Accordingly, I estimate panel error correction models, as is now commonly done in the literature

\footnotetext{
${ }^{11}$ This variable is still relatively new in the literature on current account determinants. Aizenman and Jinjarak (2009) and Fratzscher, Juvenal, and Sarno (2010) find a significant negative relation between the house price growth rate and the current account balance. However, theoretically, one might also find a positive relation between the two variables, as households could increase their savings to meet higher equity down-payments in response to rising house prices. See Geiger, Rupprecht, and Muellbauer (2015) for evidence for Germany.

${ }^{12}$ The null of no cointegration cannot be rejected only in the case of Pedroni's Panel PP-test for the reference model augmented by the credit push factor NETINTERBANKLOANS.
} 
on current account determinants (see, for example, Smith, 2011; Belke and Dreger, 2013; Gossé and Serranito, 2014). Given the restricted time dimension of the data, I derive the empirical estimates in the main specifications from an ARDL model with a maximum lag length of one. In its most general set-up, the empirical model can be formally expressed in the following way:

$$
\begin{aligned}
& \Delta C A_{i, t}=\phi_{i}\left(C A_{i, t-1}-\beta_{i, 1} R E L A T I V E G D P_{i, t-1}-\beta_{i, 2} R E A L E X R U L C_{i, t-1}\right. \\
& \left.-\beta_{i, 3} G O V B A L A N C E_{i, t-1}-\beta_{i, 4} P U L L_{i, t-1}-\beta_{i, 5} P U S H_{i, t-1}-\sum_{j=6}^{10} \beta_{i, j} X_{i, t-1}\right) \\
& +\delta_{i, 1} \Delta R E L A T I V E G D P_{i, t}+\delta_{i, 2} \Delta R E A L E X R U L C_{i, t}+\delta_{i, 3} \Delta G O V B A L A N C E_{i, t} \\
& +\delta_{i, 4} \Delta P U L L_{i, t}+\delta_{i, 5} \Delta P U S H_{i, t}+\sum_{j=6}^{10} \delta_{i, j} \Delta X_{i, j, t}+\mu_{i}+\epsilon_{i, t}
\end{aligned}
$$

Here $i$ and $t$ indicate, respectively, country and time period, $\Delta$ is the first difference operator, $X_{i, t}$ is a vector containing the additional control variables, $\beta_{i, j}$ and $\delta_{i, j}$ are, respectively, the coefficients for the long-term and short-term dynamics, $\mu_{i}$ is a countryspecific constant, $\epsilon_{i, t}$ is an i.i.d. error term and all other variables are as defined above. The bracket term constitutes the long-run relation between the current account and the explanatory variables. Of primary interest are the parameter estimates for $\beta_{i, j}$, as they indicate the change in the dependent variable caused by a permanent change in the respective independent variable. The estimate for $\phi_{i}$ measures the speed of adjustment of this error correction process. The coefficient has to be statistically significant and negative in order to show that the current account adjusts to alterations in its determinants, and can be seen as a further test regarding the cointegration relation of the variables.

Regarding the estimation strategy, I try to strike a balance between having a parsimonious model and controlling for all relevant explanatory variables. The starting point is a model that explains the current account with the determinants most commonly found in the existing literature on euro-area imbalances: the catch-up variable, the proxy for competitiveness and the fiscal balance. This reference model is then, in a first step, augmented by the different pull and push factors at a time. Based on the fit of the variables, one push factor and one pull factor are chosen. The two factors are then jointly estimated together with the variables from the reference model. Later on, the additional control variables are added (individually).

The parameters of the empirical model described above can be estimated in three different ways: with a conventional dynamic fixed effect estimator (DFE), the pooled mean group estimator (PMG, Pesaran, Shin, and Smith, 1999) or the mean group estimator (MG, Pesaran and Smith, 1995). The three estimators differ with regard to the degree of homogeneity assumed to underlie the data generation process. On the one hand, the DFE only allows the intercepts to differ, but assumes homogeneity with respect to both long-term and short-term dynamics. On the other hand, the MG assumes that both short-term and long-term dynamics are heterogeneous and relies on pooling the results of the individual country regressions. The PMG can be seen as a middle ground, as the long-run dynamics are assumed to be homogeneous, while the short-term dynamics are allowed to differ. Accordingly, the DFE estimator is the most efficient method but will produce inconsistent results if the homogeneity assumption is violated. In contrast, the consistency of the MG estimator is bought at the expense of efficiency losses.

To discriminate between the three estimators, I calculate Hausman tests. The null 
hypothesis of the test is that the difference in the coefficients is not systematic. Separate tests for the DFE and MG as well as the PMG and MG estimators are computed. In almost all cases they cannot reject the null, implying that both the DFE and PMG estimator are consistent and efficient. As the panel consists of a rather homogeneous set of countries, these test results seem plausible. However, given the small time dimension of the panel, the Hausman test could be biased. As the PMG estimator seems to strike the best balance between efficiency and consistency, it is used for the main estimations. ${ }^{13}$

\section{Credit growth and the current account}

\subsection{Main results}

Table 1 below displays the results for the estimates of the reference model augmented with the various credit proxies, with the column header indicating the respective pull or push factor used.

\begin{tabular}{|c|c|c|c|c|c|c|c|c|c|c|}
\hline Variable & $\begin{array}{l}\text { LIABIL- } \\
\text { ITIES }\end{array}$ & DEBT & LOANS & $\begin{array}{l}\text { BANK- } \\
\text { LOANS }\end{array}$ & $\begin{array}{l}\text { REAL- } \\
\text { BANK- } \\
\text { LOANS }\end{array}$ & $\begin{array}{l}\text { BANK- } \\
\text { CLAIMS }\end{array}$ & $\begin{array}{l}\text { INTER- } \\
\text { BANK- } \\
\text { CLAIMS }\end{array}$ & $\begin{array}{c}\text { NET- } \\
\text { BANK- } \\
\text { CLAIMS }\end{array}$ & $\begin{array}{c}\text { NET- } \\
\text { INTER- } \\
\text { BANK- } \\
\text { CLAIMS }\end{array}$ & $\begin{array}{c}\text { NET- } \\
\text { INTER- } \\
\text { BANK- } \\
\text { LOANS }\end{array}$ \\
\hline CREDITPROXY & $\begin{array}{l}-0.315^{* * *} \\
(0.023)\end{array}$ & $\begin{array}{l}-0.050^{* * *} \\
(0.019)\end{array}$ & $\begin{array}{l}-0.150^{* * *} \\
(0.035)\end{array}$ & $\begin{array}{l}-0.162^{* * *} \\
(0.032)\end{array}$ & $\begin{array}{l}-0.853^{* * *} \\
(0.081)\end{array}$ & $\begin{array}{c}0.046^{*} \\
(0.024)\end{array}$ & $\begin{array}{c}0.028 \\
(0.034)\end{array}$ & $\begin{array}{c}0.035 \\
(0.026)\end{array}$ & $\begin{array}{l}-0.006 \\
(0.040)\end{array}$ & $\begin{array}{l}-0.047 \\
(0.056)\end{array}$ \\
\hline RELATIVEGDP & $\begin{array}{l}0.066^{* * *} \\
(0.032)\end{array}$ & $\begin{array}{l}0.080^{* * *} \\
(0.039)\end{array}$ & $\begin{array}{l}-0.045 \\
(0.043)\end{array}$ & $\begin{array}{c}0.029 \\
(0.031)\end{array}$ & $\begin{array}{l}-0.306^{* * *} \\
(0.065)\end{array}$ & $\begin{array}{c}0.062 \\
(0.048)\end{array}$ & $\begin{array}{c}0.063 \\
(0.039)\end{array}$ & $\begin{array}{c}0.065^{*} \\
(0.035)\end{array}$ & $\begin{array}{c}0.094^{* *} \\
(0.046)\end{array}$ & $\begin{array}{l}0.093^{* *} \\
(0.044)\end{array}$ \\
\hline$R E A L E X R U L C$ & $\begin{array}{l}-0.363^{* * *} \\
(0.023)\end{array}$ & $\begin{array}{l}-0.466^{* * *} \\
(0.028)\end{array}$ & $\begin{array}{l}-0.346^{* * *} \\
(0.042)\end{array}$ & $\begin{array}{l}-0.356^{* * *} \\
(0.036)\end{array}$ & $\begin{array}{l}-0.282^{* * *} \\
(0.045)\end{array}$ & $\begin{array}{l}-0.550^{* * *} \\
(0.026)\end{array}$ & $\begin{array}{l}-0.510^{* * *} \\
(0.027)\end{array}$ & $\begin{array}{l}-0.522^{* * *} \\
(0.022)\end{array}$ & $\begin{array}{l}-0.460^{* * *} \\
(0.030)\end{array}$ & $\begin{array}{l}-0.452^{* * *} \\
(0.031)\end{array}$ \\
\hline GOVBALANCE & $\begin{array}{l}0.553^{* * *} \\
(0.084)\end{array}$ & $\begin{array}{l}0.242^{* * *} \\
(0.042)\end{array}$ & $\begin{array}{l}0.472^{* * *} \\
(0.085)\end{array}$ & $\begin{array}{l}0.328^{* * *} \\
(0.057)\end{array}$ & $\begin{array}{l}0.736^{* * *} \\
(0.064)\end{array}$ & $\begin{array}{r}0.054^{*} \\
(0.032)\end{array}$ & $\begin{array}{l}0.113^{* * *} \\
(0.033)\end{array}$ & $\begin{array}{l}0.087^{* * *} \\
(0.034)\end{array}$ & $\begin{array}{l}0.153^{* * *} \\
(0.035)\end{array}$ & $\begin{array}{l}0.161^{* * *} \\
(0.036)\end{array}$ \\
\hline Error correction & $\begin{array}{l}-0.559^{* * *} \\
(0.203)\end{array}$ & $\begin{array}{l}-0.510^{* * *} \\
(0.117)\end{array}$ & $\begin{array}{l}-0.558^{* * *} \\
(0.086)\end{array}$ & $\begin{array}{l}-0.508^{* * *} \\
(0.132)\end{array}$ & $\begin{array}{l}-0.473^{* * *} \\
(0.102)\end{array}$ & $\begin{array}{l}-0.470^{* * *} \\
(0.097)\end{array}$ & $\begin{array}{l}-0.464^{* * *} \\
(0.106)\end{array}$ & $\begin{array}{l}-0.507^{* * *} \\
(0.115)\end{array}$ & $\begin{array}{l}-0.523^{* * *} \\
(0.139)\end{array}$ & $\begin{array}{l}-0.505^{* * *} \\
(0.143)\end{array}$ \\
\hline Hausman test & $\begin{array}{c}2.030 \\
(0.730)\end{array}$ & $\begin{array}{c}1.710 \\
(0.788)\end{array}$ & $\begin{array}{c}1.130 \\
(0.889)\end{array}$ & $\begin{array}{c}0.470 \\
(0.977)\end{array}$ & $\begin{array}{c}2.700 \\
(0.609)\end{array}$ & $\begin{array}{c}0.260 \\
(0.992)\end{array}$ & $\begin{array}{c}0.470 \\
(0.977)\end{array}$ & $\begin{array}{c}0.360 \\
(0.986)\end{array}$ & $\begin{array}{l}2.350 \\
(0.673)\end{array}$ & $\begin{array}{c}1.740 \\
(0.783)\end{array}$ \\
\hline
\end{tabular}

Table 1: Pooled Mean-Group estimates for current account as a percentage of GDP: reference model augmented by various credit proxies (Notes: The table reports the long-run coefficients for the respective variables. Standard errors are in parentheses. CREDITPROXY is the push or pull factor as indicated in the column header. Error correction shows the adjustment coefficient for deviations from the long-run equilibrium relation between the variables. Hausman test reports the chi2 test statistic and the corresponding p-value for systematic differences in coefficients of the PMG estimator vs. the MG estimator. $*, * *$ and $* * *$ denote significance at the $10 \%, 5 \%$ and $1 \%$ levels respectively.)

For the credit pull factor (flows of liabilities to the domestic non-financial private sector), the results confirm the expected negative relation with the current account for all five measures. By far the largest coefficient can be recorded for the most narrowly defined proxy REALBANKLOANS. As this is also the model with the highest value for the commonly used information criteria, it is chosen as the measure for the credit pull factor. Of the five proxies for the credit push factor (flows of external debt claims of domestic banks), only $B A N K C L A I M S$ is significant and has the expected positive sign. Accordingly, this measure is chosen for the credit push factor. In all models, the

\footnotetext{
${ }^{13}$ All models are estimated with the STATA xtpmg command by Blackburne III and Frank (2007).
} 
competitiveness proxy and the fiscal balance have the expected signs and are significant.In contrast, the catch-up variable is only significant with the expected positive sign in five of the ten models. In all specifications, the adjustment coefficient is significant, implying that the current account error corrects deviations from the long-run relation with its determinants.

Table 2 below shows the results for the reference model, which includes the catch-up variable, the competitiveness proxy and the fiscal balance. The estimates for all three variables have the expected signs and are significant. When the chosen credit pull and push factors are included (baseline model I), the coefficient for the catch-up variable turns negative, the one for the competitiveness proxy gets smaller and the one for the fiscal balance is larger. Both the credit pull and push factors have the expected signs and are significant. When the catch-up variable is excluded (baseline model II), all other variables remain rightly signed, but the credit push factor is no longer significant.

\begin{tabular}{|c|c|c|c|c|c|c|c|c|c|c|}
\hline Variable & $\begin{array}{c}\text { Reference } \\
\text { model }\end{array}$ & $\begin{array}{c}\text { Baseline } \\
\text { model I }\end{array}$ & $\begin{array}{l}\text { Baseline } \\
\text { model II }\end{array}$ & $\begin{array}{c}\text { Extended } \\
\text { baseline } \\
\text { model I }\end{array}$ & $\begin{array}{c}\text { Extended } \\
\text { baseline } \\
\text { model II }\end{array}$ & $\begin{array}{c}\text { Extended } \\
\text { baseline } \\
\text { model III }\end{array}$ & $\begin{array}{c}\text { Extended } \\
\text { baseline } \\
\text { model IV }\end{array}$ & $\begin{array}{c}\text { Extended } \\
\text { baseline } \\
\text { model V }\end{array}$ & $\begin{array}{l}\text { Best fit } \\
\text { model I }\end{array}$ & $\begin{array}{l}\text { Best fit } \\
\text { model II }\end{array}$ \\
\hline RELATIVEGDP & $\begin{array}{c}0.084^{* *} \\
(0.042)\end{array}$ & $\begin{array}{l}-0.097^{* * *} \\
(0.039)\end{array}$ & & & & & & & & \\
\hline$R E A L E X R U L C$ & $\begin{array}{l}-0.483^{* * *} \\
(0.031)\end{array}$ & $\begin{array}{l}-0.092^{* *} \\
(0.041)\end{array}$ & $\begin{array}{l}-0.466^{* * *} \\
(0.041)\end{array}$ & $\begin{array}{l}-0.246^{* * *} \\
(0.022)\end{array}$ & $\begin{array}{l}-0.305^{* * *} \\
(0.038)\end{array}$ & $\begin{array}{l}-0.448^{* * *} \\
(0.034)\end{array}$ & $\begin{array}{l}-0.204^{* * *} \\
(0.037)\end{array}$ & $\begin{array}{l}-0.095^{* * *} \\
(0.030)\end{array}$ & $\begin{array}{l}-0.289^{* * *} \\
(0.031)\end{array}$ & $\begin{array}{l}-0.318^{* * *} \\
(0.015)\end{array}$ \\
\hline$G O V B A L A N C E$ & $\begin{array}{l}0.136^{* * *} \\
(0.032)\end{array}$ & $\begin{array}{l}0.388^{* * *} \\
(0.079)\end{array}$ & $\begin{array}{l}0.262^{* * *} \\
(0.085)\end{array}$ & $\begin{array}{l}0.558^{* * *} \\
(0.041)\end{array}$ & $\begin{array}{l}0.736^{* * *} \\
(0.050)\end{array}$ & $\begin{array}{l}0.301^{* * *} \\
(0.065)\end{array}$ & $\begin{array}{l}0.334^{* * *} \\
(0.091)\end{array}$ & $\begin{array}{l}0.454^{* * *} \\
(0.061)\end{array}$ & $\begin{array}{l}0.601^{* * *} \\
(0.050)\end{array}$ & $\begin{array}{l}0.422^{* * *} \\
(0.019)\end{array}$ \\
\hline PULLF ACTOR & & $\begin{array}{l}-0.404^{* * *} \\
(0.047)\end{array}$ & $\begin{array}{l}-0.701^{* * *} \\
(0.063)\end{array}$ & $\begin{array}{l}-0.555^{* * *} \\
(0.039)\end{array}$ & $\begin{array}{l}-1.311^{* * *} \\
(0.095)\end{array}$ & $\begin{array}{l}-0.611^{* * *} \\
(0.052)\end{array}$ & $\begin{array}{l}-0.250^{* * *} \\
(0.053)\end{array}$ & $\begin{array}{l}-0.481^{* * *} \\
(0.046)\end{array}$ & $\begin{array}{l}-0.556^{* * *} \\
(0.053)\end{array}$ & $\begin{array}{l}-0.391^{* * *} \\
(0.018)\end{array}$ \\
\hline PUSHFACTOR & & $\begin{array}{l}0.118^{* * *} \\
(0.020)\end{array}$ & $\begin{array}{c}0.009 \\
(0.026)\end{array}$ & $\begin{array}{l}0.045^{* * *} \\
(0.011)\end{array}$ & $\begin{array}{l}-0.247^{* * *} \\
(0.091)\end{array}$ & $\begin{array}{l}-0.027 \\
(0.021)\end{array}$ & $\begin{array}{l}0.090^{* * *} \\
(0.014)\end{array}$ & $\begin{array}{l}0.046^{* * *} \\
(0.011)\end{array}$ & $\begin{array}{c}0.030^{* *} \\
(0.015)\end{array}$ & $\begin{array}{l}0.038^{* * *} \\
(0.011)\end{array}$ \\
\hline$D E P E N D E N C Y$ & & & & $\begin{array}{l}-0.551^{* * *} \\
(0.103)\end{array}$ & & & & & $\begin{array}{l}-0.749^{* * *} \\
(0.116)\end{array}$ & $\begin{array}{l}-0.322^{* * *} \\
(0.060)\end{array}$ \\
\hline POPULATION & & & & & $\begin{array}{l}-3.049^{* * *} \\
(1.134)\end{array}$ & & & & & \\
\hline$N F A_{t-1}$ & & & & & & $\begin{array}{l}-0.028^{* * *} \\
(0.003)\end{array}$ & & & & \\
\hline HOUSEPRICE & & & & & & & $\begin{array}{l}-0.151^{* * *} \\
(0.035)\end{array}$ & & $\begin{array}{l}-0.070^{* * *} \\
(0.015)\end{array}$ & \\
\hline INTEREST & & & & & & & & $\begin{array}{l}0.714^{* * *} \\
(0.084)\end{array}$ & & $\begin{array}{l}0.232^{* * *} \\
(0.028)\end{array}$ \\
\hline Error correction & $\begin{array}{l}-0.492^{* * *} \\
(0.121)\end{array}$ & $\begin{array}{l}-0.419^{* * *} \\
(0.146) \\
\end{array}$ & $\begin{array}{l}-0.456^{* * *} \\
(0.085)\end{array}$ & $\begin{array}{l}-0.603^{* * *} \\
(0.137)\end{array}$ & $\begin{array}{l}-0.339^{\text {*** }} \\
(0.122)\end{array}$ & $\begin{array}{l}-0.558^{* * *} \\
(0.121)\end{array}$ & $\begin{array}{l}-0.497^{* * *} \\
(0.150)\end{array}$ & $\begin{array}{l}-0.509^{* * *} \\
(0.099)\end{array}$ & $\begin{array}{l}-0.564^{* * *} \\
(0.112)\end{array}$ & $\begin{array}{l}-0.712^{* * *} \\
(0.138)\end{array}$ \\
\hline Hausman test & $\begin{array}{c}0.620 \\
(0.893)\end{array}$ & $\begin{array}{c}0.120 \\
(1.000)\end{array}$ & $\begin{array}{c}1.200 \\
(0.879)\end{array}$ & $\begin{array}{c}0.090 \\
(1.000)\end{array}$ & $\begin{array}{c}4.410 \\
(0.492)\end{array}$ & $\begin{array}{c}2.970 \\
(0.704)\end{array}$ & $\begin{array}{c}1.510 \\
(0.912)\end{array}$ & $\begin{array}{l}1.480 \\
(0.916)\end{array}$ & $\begin{array}{c}0.000 \\
(1.000)\end{array}$ & $\begin{array}{c}0.000 \\
(1.000)\end{array}$ \\
\hline
\end{tabular}

Table 2: Pooled Mean-Group estimates for current account as a percentage of GDP: baseline models and extensions (Notes: The table reports the long-run coefficients for the respective variables. Standard errors are in parentheses. PULLFACTOR corresponds to flows of bank loans to the domestic non-financial private sector excluding loans for house purchases. PUSHF ACTOR corresponds to flows of debt claims of domestic banks on debtors in other euro-area countries. Error correction shows the adjustment coefficient for deviations from the long-run equilibrium relation between the variables. Hausman test reports the chi2 test statistic and the corresponding p-value for systematic differences in coefficients of the PMG estimator vs. the MG estimator. $*, * *$ and $* * *$ denote significance at the $10 \%$, $5 \%$ and $1 \%$ levels respectively.)

In a next step, I augment baseline model I with the five control variables at a time. As the catch-up variable either has the wrong sign or is insignificant in all but the specification with the house price growth rate, I choose to drop it in order to save degrees of freedom. ${ }^{14}$

\footnotetext{
${ }^{14}$ To ensure that the choice of the credit proxies is not biased by the inclusion of the catch-up variable,
} 
Instead, I estimate baseline model II extended by the control variables. Table 2 above shows the results as extended baseline models I to V. The parameter estimates for the credit pull factor, the competitiveness proxy and the fiscal balance stay rightly signed and significant in all specifications. Whereas the coefficients for the first two variables are, in general, smaller than in baseline model II, they increase for the last one. The credit push factor is significant and rightly signed in three of the five models. All additional controls are significant and, with the exception of the net international investment position, have the right sign. ${ }^{15}$

I then estimate all possible pairwise combinations of the five additional control variables. ${ }^{16}$ Of all these combinations, the two including the dependency ratio and, respectively, the long-term interest rate or the house price growth rate have all coefficients rightly signed and statistically significant. The parameter estimates are reported as best fit models I and II in Table 2 above and confirm the previous results. All other specifications with pairwise combinations of the five control variables either have insignificant or wrongly signed variables. ${ }^{17}$ In all models considered, the error correction parameter $\phi_{i}$ is significant and negative, implying that the current account adjusts to changes in the explanatory variables.

The median coefficient of -0.6 for the credit pull factor implies that a one percentage point increase in the flow of bank loans to the non-financial private sector is associated with a 0.6 percentage point decrease in the current account balance. The median coefficient of 0.04 for the credit push factor is considerably smaller and implies that a one percentage point increase in the flow of claims against debtors in other euro-area countries is associated with an 0.04 percentage point increase in the current account balance.

\subsection{Robustness checks}

To check the validity of the results, I conduct a variety of robustness checks. Firstly, to confirm that the results are not driven by the inclusion of a particular country, I recalculate best fit model II excluding one country at a time (see Table 8 in the appendix). In almost all models, the coefficients stay significant with the right sign and do not change much in terms of size. ${ }^{18}$ The only exceptions are the specifications excluding Finland, France and Ireland. In all three cases the coefficient for the credit push factor either turns negative or insignificant. ${ }^{19}$ In the specification excluding France, the competitiveness proxy and the dependency ratio are no longer significant and the coefficient estimates for the remaining

I also re-estimate the reference model augmented by the credit measures without the catch-up variable. The results confirm the choice of the two measures and are available upon request.

${ }^{15}$ Following Schoder, Proano, and Semmler (2013), the negative sign can be interpreted as an indicator of unsustainable dynamics in the net international investment positions of euro-area countries.

${ }^{16}$ Given the limited degrees of freedom, it is impossible to estimate more complex models.

${ }^{17}$ The results are available upon request.

${ }^{18}$ When Belgium is excluded the parameters of the model cannot be estimated.

${ }^{19}$ According to the estimates by Hobza and Zeugner (2014), France acted as an intermediary for funds from the rest of the world to the deficit countries, while its current account was roughly in balance. Accordingly, the inclusion of France could potentially downward bias the estimates of the domestic push factor. The same effect could be expected for Ireland, as the analysis of the descriptives statistics above has shown. The results for the models excluding France and Ireland suggest that this concern is not warranted. 
variables are considerably larger. All models confirm that the current account adjusts to deviations from its long-term relation with the explanatory variables.

In order to check the accuracy of the chosen credit pull and push factors, I recalculate best fit model II with all ten different credit proxies at a time (see Table 9 in the appendix). ${ }^{20}$ As in the augmented reference model, the coefficients for the credit pull factor are always significant and become bigger the narrower the measure is defined. Again, the model with REALBANKLOANS has the best fit according to information criteria. The domestic credit push factors are insignificant when measured on a gross basis, and significant but with the wrong sign when measured on a net basis. With a few exceptions, the parameter estimates for the other variables also retain the right signs and are significant.

One reason why the credit push factors are insignificant or wrongly signed might be that the capital flight during the height of the euro-area crisis is not adequately captured in the data. During that period, banks in the deficit countries strongly increased their refinancing operations with the Eurosystem to cover outflows of private funds, which was then reflected in rising TARGET2 balances (see, for example, Sinn and Wollmershäuser, 2012; Abad, Löffler, Schnabl, and Zemanek, 2013). ${ }^{21}$ Accordingly, I construct push factors corrected for the annual change in the TARGET2 balance of the respective national central bank. ${ }^{22}$ As the TARGET2 balances were already fluctuating quite heavily before the crisis for reasons unrelated to the capital flight, I correct the push factors only from 2008 onwards. Since they also reflect an outflow of funds from the respective government bond markets, which was absorbed by domestic banks increasing their exposure to their own sovereign, the resulting variables and the estimation results have to be treated with caution.

Table 10 in the appendix shows the results when the push factors corrected for changes in TARGET2 balances are included in the reference model as well as baseline model II including the credit pull factor REALBANKLOANS. As the Hausman test indicates systematic differences in coefficients in four of the ten models, the mean group estimator is used in these cases to ensure consistency. When the push factors are estimated in the augmented reference model excluding the pull factor, the coefficients are rightly signed and significant in three of five models and tend to be larger. However, once the pull factor is included the coefficients are still rightly signed and slightly larger but turn insignificant in four of the five cases. In contrast, the coefficients for the pull factor are always correctly signed, highly significant and bigger. Overall, the estimations with the TARGET2 corrected push factors confirm the previous results.

In the following step, all models are re-estimated with the DFE estimator, assuming that also the short-term dynamics are homogeneous (see Table 11 in the appendix). The table reports standard errors clustered at the country level to address potential within group (serial) correlation of the error term. As a further robustness check, I also estimate models with standard errors clustered at the time level as well as uncorrected standard

\footnotetext{
${ }^{20}$ I choose best fit model II over best fit model I as it has the better fit according to information criteria. The following results also hold when the credit pull and push factors are included individually in best fit model I, and are available upon request.

${ }^{21}$ I also experimented with credit push factors that take into account claims against and liabilities to sectors outside the euro area. The estimates likewise did not give any significant results and are available upon request.

${ }^{22}$ The data were obtained from http://www.eurocrisismonitor.com/.
} 
errors and report if they produce a different inference. ${ }^{23}$ The estimations reveal that, while the coefficients for the credit pull factor stay significant in all specifications and tend to be higher, the coefficients for the credit push factor retain the right sign, but are always insignificant. The fiscal balance stays significant and rightly signed in eight of the ten models, while the competitiveness proxy always retains the right sign but is insignificant in six of the ten specifications. The reverse picture emerges when standard errors are clustered at the time level: The competitiveness proxy is always correctly signed and significant, while for the fiscal balance, this is only the case in five out of ten models. The results for the additional control variables are mixed, with only the long-term interest rate and the house price growth rate showing the right sign and significance. In all models, the current account error corrects in response to changes of the independent variables and the point estimates do not in general change much in terms of size.

As the relaxation of the heterogeneity assumption regarding the short-term dynamics frees degrees of freedom, more complex models can be estimated. As the first step, I address the potential concern that the time series are driven by a linear trend in combination with a structural break. I do so by including a time trend as well as a crisis dummy that is set to one from the beginning of the adjustment process in 2008 onwards and zero otherwise into the cointegration relation. The results are reported in Table 12 in the appendix. Whereas both the linear trend and the crisis dummy are significant in all but the reference model, the estimates for the remaining variables are largely the same both in terms of significance and size, irrespective of whether standard errors are clustered at the country or time level. In particular, the credit pull factor remains statistically significant and rightly signed in all models, whereas the credit push factor is always insignificant.

To address potential endogeneity concerns, I then instead augment the models with two additional lagged differences (see Table 13 in the appendix). Given the yearly time dimension of the data, this should be a rather conservative choice. With respect to the credit pull and push factor the previous estimates with the DFE estimator are confirmed: The credit pull factor is significant and rightly signed in all but the extended baseline model III when errors are clustered at the country level. In contrast, the credit push factor is again insignificant in all specifications. In terms of the main control variables, the fiscal balance is significant but wrongly signed in the reference model and insignificant in all others. The competitiveness proxy is significant and rightly signed in all but the extended baseline models II and IV when standard errors are clustered at the time level.

In order to check whether a common unobserved factor biases the estimation results, I include cross-sectional averages of the dependent variable as well as the explanatory variables in spirit of the Common Correlated Effects Pooled Mean Group (CCEPMG) approach developed by Pesaran (2006) and Pesaran and Chudik (2013) in the baseline specifications. The results are shown in Table 14 in the appendix. The estimates once more confirm that the credit pull factor has a statistically significant and sizable negative impact on the current account, whereas the credit push factor is always rightly signed but statistically insignificant. The competitiveness proxy is rightly signed and significant in seven of the ten models when standard errors are clustered at the country level and in all specifications when standard errors are clustered at the time level. In contrast, the fiscal

\footnotetext{
${ }^{23}$ Clustering standard errors at the time level can be seen as a remedy against a common unobserved factor. Since clustered standard errors might be biased downwards when the number of clusters is low, I also calculate uncorrected standard errors as both the time and cross-section dimension are rather small.
} 
balance is always insignificant or wrongly signed.

As a further robustness check, I relax the assumption of non-stationarity and cointegration of the variables and estimate the (long-term) relation between the current account and its determinants with a static fixed effects estimator in levels (see Table 15 in the appendix). For the credit pull factor as well as the competitiveness proxy and the fiscal balance the results once more confirm the statistically significant impact on the current account. The coefficients of the credit push factor are again always insignificant and most of the time also have the wrong sign.

Finally, to further mitigate endogeneity concerns, I recalculate the static models using instrumented variables (see Table 16 in the appendix). Given the absence of other strong instruments, I simply use the first lag of the respective variable. ${ }^{24}$ Once more, the credit pull factor is significant in all models and the coefficients even tend to be bigger. In contrast, the credit push factor is again insignificant in all specifications and, in most cases, has the wrong sign. The coefficient for the competitiveness proxy is only significant in four of the ten models estimated and also tends to be smaller. By contrast, the estimates confirm the causal influence of the fiscal balance as well as the house price growth rate and the long-term interest rate.

\subsection{Economic importance of explanatory variables}

So far, the paper has been mostly concerned with statistical significance. In a next step, I use the parameter estimates to disentangle how far the various explanatory variables contributed to the build-up of the current account imbalances before the crisis as well as their subsequent correction over the last years. To this end, I multiply the change in the various explanatory variables between 1999 (beginning of the time series) and 2007 (peak of the current account imbalances) for all countries considered with the long-run coefficients from best fit model II. These values are then plotted against the actual change in the current account over this period.

As Figure 3 below shows, the increase in flows of bank loans to the domestic nonfinancial private sector (credit pull factor) contributed strongly to the deterioration of the current account in both Ireland and Spain. A loss of competitiveness played a major role as well. An increase in the credit pull factor led to a sizeable expansion of the current account deficit in Greece. Here, the fiscal balance also played a considerable part. For Portugal, the deterioration of the current account was mainly due to a loss of competitiveness. In Italy, an increase in the credit pull factor made the strongest contribution to the worsening of the current account deficit followed by an increase in the dependency ratio. If one were to repeat the same exercise based on the coefficient estimates of best fit model I, the contribution of the credit pull factor would be even larger. Turning to the countries that saw the biggest improvement in their current accounts Austria, Germany and the Netherlands - it becomes apparent that a large part of that change remains unexplained. ${ }^{25}$ The calculations also show that the increase in flows of claims of domestic banks on debtors in other euro-area countries (credit push factor)

\footnotetext{
${ }^{24}$ As the net international investment position already enters as the stock at the end of the previous period, this variable is not instrumented.

${ }^{25}$ On the difficulties in explaining the current account surpluses of euro-area countries, see European Commission (2012).
} 
played only a very limited role in the build-up of the large current account surpluses. For Austria and Germany, an improvement in competitiveness had the biggest positive impact.

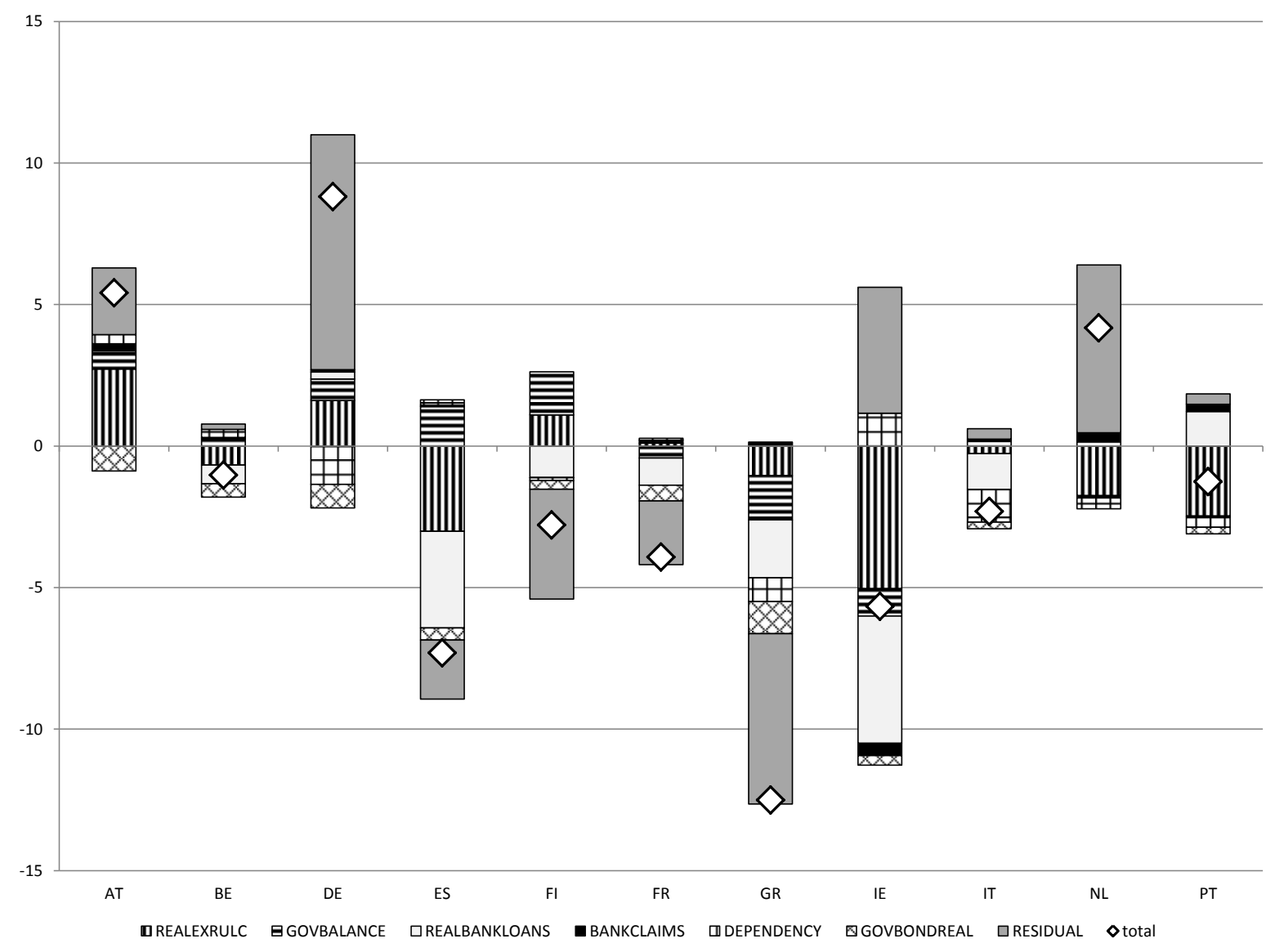

Figure 3: Growth contributions to the change in the current account balance during the build-up phase of current account imbalances (The graph shows the change in the current account between 1999 (beginning of the time series) and 2007 (peak of the current account imbalances) and the respective growth contributions of the explanatory variables. The growth contributions are obtained by multiplying the change in a variable over the time period with the long-run coefficients from best fit model II.)

I repeat the exercise for the adjustment period from 2007 to 2013 (end of the time series). Figure 4 below shows the results. Here, the picture is even more clear-cut: Almost the entire improvement in the current account in the crisis countries Spain, Greece, Ireland, Italy and Portugal was due to the collapse of flows of loans to the domestic non-financial private sector. Only in Ireland did improvements in competitiveness have a recognizably positive impact on the current account. Rising interest rates led in all countries to an improvement in the current account, with the effect being especially strong in Greece. The calculations also reveal that the deterioration of fiscal balances counteracted the improvements stemming from the credit pull factor. 


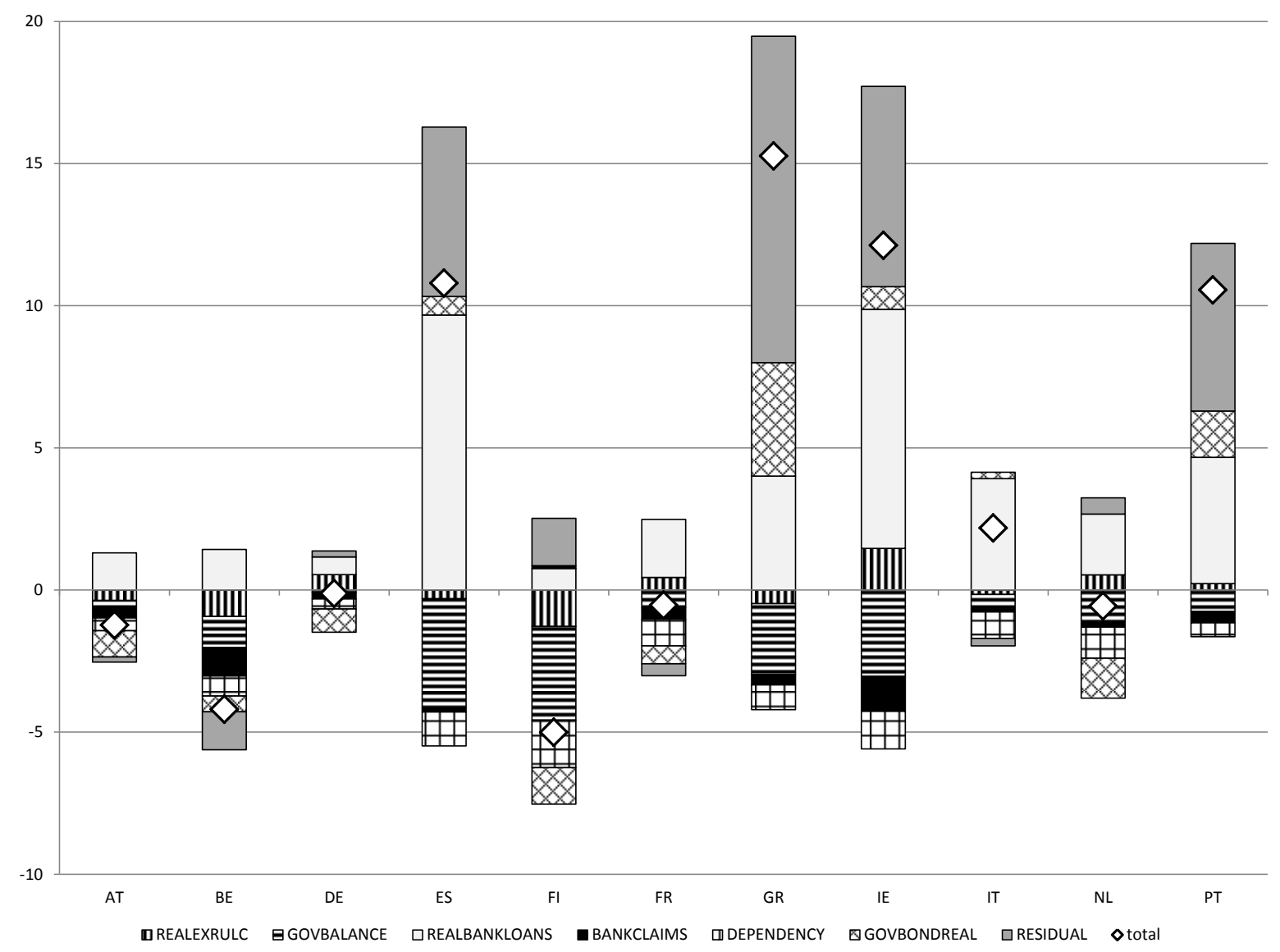

Figure 4: Growth contributions to the change in the current account balance during the adjustment phase of current account imbalances (The graph shows the change in the current account between 2007 (peak of the current account imbalances) and 2013 (end of the time series) and the respective growth contributions of the explanatory variables. The growth contributions are obtained by multiplying the change in a variable over the time period with the long-run coefficients from best fit model II.)

\section{Conclusions}

In this paper, I estimate the impact of credit growth on the current account balance of euro-area countries, distinguishing between a credit pull and a credit push factor. The credit pull factor captures flows of bank loans to the domestic non-financial private sector. An increase in these flows is assumed to raise domestic demand, draw in additional imports and lead to a deterioration of the current account. The credit push factor measures flows of claims of domestic banks on debtors in other euro-area countries. An increase in these flows channels savings abroad and should be associated with an improvement in the current account.

The empirical estimates confirm that the credit pull factor has a statistically significant impact on the current account of euro-area countries. In contrast, the coefficient for the credit push factor is not significant and rightly signed in various specifications and tends to be substantially smaller. In addition to the credit pull factor, a competitiveness proxy, the fiscal balance as well as the the long-term interest rate are found to be significant 
determinants of the current account balance of euro-area countries. The idea that euroarea current account developments are the result of a catch-up process by lower-income countries is, however, rejected by the data.

A decomposition of the growth contributions of the respective explanatory variables to the change in the current account shows that variations in the flow of loans to the domestic non-financial private sector - together with changes in competitiveness - constituted the most important factor driving the build-up of current account imbalances in the deficit countries. As the credit boom pushed domestic demand above potential output, current account deficits surged. Furthermore, most of the improvement in the deficit countries' current accounts is due to the collapse of flows of loans to the domestic non-financial private sector, which depressed domestic demand and led to a correction of the current account imbalances. In contrast, the estimates suggest that changes in flows of banks' debt claims on other euro-area countries did not have a sizable impact on the current account balances of the euro-area surplus countries.

The findings have important policy implications. The widely held notion that sustaining competitiveness is important for limiting the build-up of large current account deficits is confirmed. However, the results suggest that impeding an increase in indebtedness will not only strengthen the resilience of the private sector, but can also be seen as a promising way to dampen the formation of unsustainable current account imbalances in euro-area countries. Due to the asymmetric nature of these credit developments, policy measures at the national level seem to be the most appropriate policy tool (see Brzoza-Brzezina, Kolasa, and Makarski, 2015). The findings also confirm the important role played by fiscal policy: If the build-up of excessive indebtedness by the non-financial sector cannot be tamed, running (large) fiscal surpluses can help to keep the current account (more) in balance (see Polito and Wickens, 2014).

The estimation results can also be used to assess the sustainability of the adjustment process in the deficit countries. In the course of economic recovery, the flows of bank loans to the domestic non-financial private sector should strengthen again. Taken by itself, that should worsen the current account balances once more. However, part of this development should be counteracted by the continuation of fiscal policy tightening. As most other determinants of the current account balances are beyond the control of policymakers, further (relative) improvements in competitiveness seem to be the most promising way to stabilize the adjustment progress made over the past few years. 


\section{A Data sources}

\begin{tabular}{|c|c|c|c|}
\hline Variable & Data source & Time series & Transformation \\
\hline $\mathrm{CA}$ & AMECO & $\begin{array}{l}\text { Balance on current transactions with the rest of the world } \\
\text { (Percentage of GDP at market prices) }\end{array}$ & none \\
\hline REALEXRULC & SDW & $\begin{array}{l}\text { Real harmonised competitiveness indicator ULC in total } \\
\text { economy deflated, Euro area-18 countries vis-a-vis the } \\
\text { EER-20 group of trading partners }\end{array}$ & divided by euro-area value \\
\hline GOVBALANCE & AMECO & $\begin{array}{l}\text { Net lending }(+) \text { or net borrowing }(-) \text { : general government } \\
\text { (Percentage of GDP at market prices) }\end{array}$ & none \\
\hline DEPENDENCY & WDI & Age dependency ratio & none \\
\hline HOUSEPRICE & SDW & Residential property prices & $\begin{array}{l}\text { year-on-year growth rate, } \\
\text { deflated by HCPI }\end{array}$ \\
\hline INTEREST & AMECO & EMU convergence criterion series & $\begin{array}{l}\text { yearly average, } \\
\text { deflated by HCPI }\end{array}$ \\
\hline LIABILITIES & SDW & $\begin{array}{l}\text { Transactions in financial instruments - All financial assets } \\
\text { and liabilities }\end{array}$ & $\begin{array}{l}\text { flows annualized, divided } \\
\text { by GDP at market prices }\end{array}$ \\
\hline DEBT & SDW & $\begin{array}{l}\text { Transactions in financial instruments - Securities other than } \\
\text { shares, excluding financial derivatives / Loans }\end{array}$ & $\begin{array}{l}\text { flows annualized, divided } \\
\text { by GDP at market prices }\end{array}$ \\
\hline REALBANKLOANS & SDW & $\begin{array}{l}\text { BANKLOANS minus Financial transactions (flows) - Lending } \\
\text { for house purchase - Euro area counterpart, Households and } \\
\text { non-profit institutions serving households (S.14 and S.15) }\end{array}$ & $\begin{array}{l}\text { flows annualized, divided } \\
\text { by GDP at market prices }\end{array}$ \\
\hline BANKCLAIMS & SDW & $\begin{array}{l}\text { Financial transactions (flows) - Loans plus Debt securities held - } \\
\text { Other Euro area member states counterpart, Monetary financial } \\
\text { institutions (MFIs) and Non-MFIs sector }\end{array}$ & $\begin{array}{l}\text { flows annualized, divided } \\
\text { by GDP at market prices }\end{array}$ \\
\hline INTERBANKCLAIMS & SDW & $\begin{array}{l}\text { Financial transactions (flows) - Loans plus Debt securities held - } \\
\text { Other Euro area member states counterpart, Monetary financial } \\
\text { institutions (MFIs) sector }\end{array}$ & $\begin{array}{l}\text { flows annualized, divided } \\
\text { by GDP at market prices }\end{array}$ \\
\hline NETBANKCLAIMS & SDW & $\begin{array}{l}\text { BANKCLAIMS minus Financial transactions (flows) - Deposit } \\
\text { liabilities - Other Euro area member states counterpart, } \\
\text { Monetary financial institutions (MFIs) and Non-MFIs sector }\end{array}$ & $\begin{array}{l}\text { flows annualized, divided } \\
\text { by GDP at market prices }\end{array}$ \\
\hline NETINTERBANKCLAIMS & SDW & $\begin{array}{l}\text { INTERBANKCLAIMS minus Financial transactions (flows)- } \\
\text { Deposit liabilities - Other Euro area member states counterpart, } \\
\text { Monetary financial institutions (MFIs) sector }\end{array}$ & $\begin{array}{l}\text { flows annualized, divided } \\
\text { by GDP at market prices }\end{array}$ \\
\hline NETINTERBANKLOANS & SDW & $\begin{array}{l}\text { Financial transactions (flows) - Loans minus Deposits - Other } \\
\text { Euro area member states counterpart, Monetary financial } \\
\text { institutions (MFIs) sector }\end{array}$ & $\begin{array}{l}\text { flows annualized, divided } \\
\text { by GDP at market prices }\end{array}$ \\
\hline
\end{tabular}

Table 3: Data sources (Notes: AMECO is the Annual Macro-Economic Database of the European Commission, SDW is the Statistical Data Warehouse of the ECB. WDI are the World Development Indicators of the Worldbank.) 


\section{B Unit root and cointegration tests}

\begin{tabular}{|c|c|c|c|c|c|c|c|}
\hline \multirow[b]{2}{*}{ Variable } & \multirow[t]{2}{*}{ Model } & \multicolumn{2}{|c|}{ IPS } & \multicolumn{2}{|c|}{ Breitung } & \multicolumn{2}{|c|}{ CADF } \\
\hline & & test stat. & $\mathrm{p}$-value & test stat. & p-value & test stat. & $\mathrm{p}$-value \\
\hline \multirow[t]{2}{*}{$\mathrm{CA}$} & Constant & 3.144 & 0.999 & -0.157 & 0.438 & -1.186 & 0.951 \\
\hline & Constant \& trend & 4.384 & 1.000 & 1.446 & 0.926 & -1.370 & 0.996 \\
\hline \multirow[t]{2}{*}{$\Delta \mathrm{CA}$} & Constant & -4.755 & 0.000 & -1.543 & 0.061 & -1.879 & 0.325 \\
\hline & Constant \& trend & -4.038 & 0.000 & -2.674 & 0.004 & -2.506 & 0.231 \\
\hline \multirow[t]{2}{*}{ RELATIVEGDP } & Constant & -2.301 & 0.011 & -0.706 & 0.240 & -2.406 & 0.020 \\
\hline & Constant \& trend & -0.457 & 0.324 & 1.374 & 0.915 & -2.888 & 0.030 \\
\hline \multirow[t]{2}{*}{$\Delta$ RELATIVEGDP } & Constant & -4.423 & 0.000 & -3.166 & 0.001 & -2.907 & 0.000 \\
\hline & Constant \& trend & -4.197 & 0.000 & -3.979 & 0.000 & -2.765 & 0.066 \\
\hline \multirow[t]{2}{*}{ REALEXRULC } & Constant & -0.552 & 0.290 & -0.141 & 0.444 & -1.992 & 0.213 \\
\hline & Constant \& trend & 4.869 & 1.000 & 2.566 & 0.995 & -2.387 & 0.352 \\
\hline \multirow[t]{2}{*}{$\Delta$ REALEXRULC } & Constant & -2.237 & 0.013 & -3.330 & 0.000 & -2.428 & 0.017 \\
\hline & Constant \& trend & -3.543 & 0.000 & -1.215 & 0.112 & -3.282 & 0.001 \\
\hline \multirow[t]{2}{*}{ GOVBALANCE } & Constant & -0.859 & 0.195 & -1.698 & 0.045 & -1.971 & 0.232 \\
\hline & Constant \& trend & -1.118 & 0.132 & -1.044 & 0.148 & -2.327 & 0.420 \\
\hline \multirow[t]{2}{*}{$\Delta$ GOVBALANCE } & Constant & -9.006 & 0.000 & -3.949 & 0.000 & -2.174 & 0.088 \\
\hline & Constant \& trend & -5.514 & 0.000 & -3.023 & 0.001 & -1.851 & 0.889 \\
\hline \multirow[t]{2}{*}{ DEPENDENCY } & Constant & -6.163 & 0.000 & 0.956 & 0.831 & -1.954 & 0.248 \\
\hline & Constant \& trend & -0.946 & 0.172 & 4.788 & 1.000 & -2.010 & 0.772 \\
\hline \multirow[t]{2}{*}{$\Delta$ DEPENDENCY } & Constant & 1.050 & 0.853 & 1.408 & 0.921 & -1.659 & 0.586 \\
\hline & Constant \& trend & 2.696 & 0.997 & 2.377 & 0.991 & -2.552 & 0.192 \\
\hline \multirow[t]{2}{*}{ POPULATION } & Constant & 0.068 & 0.527 & -0.951 & 0.171 & -1.700 & 0.536 \\
\hline & Constant \& trend & -0.645 & 0.260 & 0.962 & 0.832 & -2.439 & 0.297 \\
\hline \multirow[t]{2}{*}{$\Delta$ POPULATION } & Constant & -5.364 & 0.000 & -4.539 & 0.000 & -2.447 & 0.015 \\
\hline & Constant \& trend & -5.408 & 0.000 & -2.154 & 0.016 & -2.056 & 0.729 \\
\hline \multirow[t]{2}{*}{$N F A_{t-1}$} & Constant & 2.941 & 0.998 & 0.584 & 0.720 & -1.304 & 0.902 \\
\hline & Constant \& trend & -1.741 & 0.041 & -1.663 & 0.048 & -1.731 & 0.943 \\
\hline \multirow[t]{2}{*}{$\Delta N F A_{t-1}$} & Constant & -8.504 & 0.000 & -0.833 & 0.202 & -2.548 & 0.006 \\
\hline & Constant \& trend & -6.568 & 0.000 & -0.675 & 0.250 & -3.428 & 0.000 \\
\hline \multirow[t]{2}{*}{ HOUSEPRICE } & Constant & -0.786 & 0.216 & -0.978 & 0.164 & -2.981 & 0.000 \\
\hline & Constant \& trend & -3.174 & 0.001 & 0.416 & 0.661 & -2.601 & 0.154 \\
\hline \multirow[t]{2}{*}{$\Delta$ HOUSEPRICE } & Constant & -6.848 & 0.000 & -5.053 & 0.000 & -2.319 & 0.037 \\
\hline & Constant \& trend & -3.782 & 0.000 & -1.519 & 0.064 & -2.610 & 0.148 \\
\hline \multirow[t]{2}{*}{ INTEREST } & Constant & -0.045 & 0.482 & -1.127 & 0.130 & -2.409 & 0.019 \\
\hline & Constant \& trend & -0.461 & 0.322 & 0.525 & 0.700 & -3.726 & 0.000 \\
\hline \multirow[t]{2}{*}{$\Delta$ INTEREST } & Constant & -7.433 & 0.000 & -3.584 & 0.000 & -3.285 & 0.000 \\
\hline & Constant \& trend & -5.807 & 0.000 & 3.713 & 1.000 & -2.895 & 0.029 \\
\hline
\end{tabular}

Table 4: Unit root tests: Current account and control variables (Notes: IPS is the Im-PesaranShin unit-root test, and CADF is the Pesaran CADF test. The null hypothesis for all tests is that all panels contain unit roots. In the IPS and Breitung tests, the cross-sectional means are removed. In the CADF tests, the cross-sectional average is extracted in the first period and extreme t-values are truncated.) 


\begin{tabular}{|c|c|c|c|c|c|c|c|}
\hline \multirow[b]{2}{*}{ Variable } & \multirow[t]{2}{*}{ Model } & \multicolumn{2}{|c|}{ IPS } & \multicolumn{2}{|c|}{ Breitung } & \multicolumn{2}{|c|}{$\mathrm{CADF}$} \\
\hline & & test stat. & p-value & test stat. & p-value & test stat. & p-value \\
\hline \multirow[t]{2}{*}{ LIABILITIES } & Constant & -2.497 & 0.006 & -3.741 & 0.000 & -2.262 & 0.053 \\
\hline & Constant \& trend & -2.160 & 0.015 & -2.854 & 0.002 & -2.864 & 0.036 \\
\hline \multirow[t]{2}{*}{$\Delta$ LIABILITIES } & Constant & -10.632 & 0.000 & -5.154 & 0.000 & -2.940 & 0.000 \\
\hline & Constant \& trend & -8.311 & 0.000 & -3.741 & 0.000 & -3.029 & 0.011 \\
\hline \multirow{2}{*}{ DEBT } & Constant & -1.625 & 0.052 & -1.278 & 0.101 & -2.242 & 0.060 \\
\hline & Constant \& trend & 0.064 & 0.526 & -0.223 & 0.412 & -2.047 & 0.738 \\
\hline \multirow{2}{*}{$\Delta$ DEBT } & Constant & -8.438 & 0.000 & -4.863 & 0.000 & -2.485 & 0.011 \\
\hline & Constant \& trend & -7.307 & 0.000 & -6.578 & 0.000 & -2.884 & 0.031 \\
\hline \multirow[t]{2}{*}{ LOANS } & Constant & -1.954 & 0.025 & -1.393 & 0.082 & -1.778 & 0.442 \\
\hline & Constant \& trend & -1.364 & 0.086 & -0.367 & 0.357 & -1.870 & 0.878 \\
\hline \multirow[t]{2}{*}{$\Delta$ LOANS } & Constant & -9.575 & 0.000 & -4.853 & 0.000 & -2.342 & 0.031 \\
\hline & Constant \& trend & -7.975 & 0.000 & -7.054 & 0.000 & -2.323 & 0.426 \\
\hline \multirow[t]{2}{*}{ BANKLOANS } & Constant & 0.201 & 0.580 & -1.313 & 0.095 & -2.360 & 0.028 \\
\hline & Constant \& trend & -0.025 & 0.490 & -0.323 & 0.373 & -2.123 & 0.659 \\
\hline \multirow[t]{2}{*}{$\Delta$ BANKLOANS } & Constant & -5.245 & 0.000 & -4.184 & 0.000 & -2.149 & 0.101 \\
\hline & Constant \& trend & -2.905 & 0.002 & -2.182 & 0.015 & -2.313 & 0.437 \\
\hline \multirow{2}{*}{ REALBANKLOANS } & Constant & -0.480 & 0.316 & -1.661 & 0.048 & -2.124 & 0.116 \\
\hline & Constant \& trend & -0.616 & 0.269 & -0.687 & 0.246 & -2.095 & 0.689 \\
\hline \multirow{2}{*}{$\Delta$ REALBANKLOANS } & Constant & -6.475 & 0.000 & -4.079 & 0.000 & -2.122 & 0.116 \\
\hline & Constant \& trend & -4.568 & 0.000 & -2.550 & 0.005 & -2.189 & 0.584 \\
\hline \multirow[t]{2}{*}{ BANKCLAIMS } & Constant & -1.811 & 0.035 & -1.062 & 0.144 & -3.073 & 0.000 \\
\hline & Constant \& trend & -3.927 & 0.000 & -2.453 & 0.007 & -3.842 & 0.000 \\
\hline \multirow[t]{2}{*}{$\Delta$ BANKCLAIMS } & Constant & -12.172 & 0.000 & -2.845 & 0.002 & -4.179 & 0.000 \\
\hline & Constant \& trend & -8.518 & 0.000 & -2.310 & 0.011 & -4.090 & 0.000 \\
\hline \multirow[t]{2}{*}{ INTERBANKCLAIMS } & Constant & -2.756 & 0.003 & -2.358 & 0.009 & -2.951 & 0.000 \\
\hline & Constant \& trend & -3.841 & 0.000 & -2.405 & 0.008 & -3.179 & 0.003 \\
\hline \multirow[t]{2}{*}{$\Delta$ INTERBANKCLAIMS } & Constant & -11.352 & 0.000 & -3.932 & 0.000 & -3.572 & 0.000 \\
\hline & Constant \& trend & -8.226 & 0.000 & -2.862 & 0.002 & 3.390 & 0.000 \\
\hline \multirow[t]{2}{*}{ NETBANKCLAIMS } & Constant & -5.747 & 0.000 & -2.698 & 0.004 & -3.276 & 0.000 \\
\hline & Constant \& trend & -5.861 & 0.000 & -2.529 & 0.006 & -3.282 & 0.001 \\
\hline \multirow[t]{2}{*}{$\Delta$ NETBANKCLAIMS } & Constant & -10.922 & 0.000 & -3.267 & 0.001 & -3.793 & 0.000 \\
\hline & Constant \& trend & -7.777 & 0.000 & -2.403 & 0.008 & -3.691 & 0.000 \\
\hline \multirow[t]{2}{*}{ NETINTERBANKCLAIMS } & Constant & -6.686 & 0.000 & -3.301 & 0.001 & -1.016 & 0.985 \\
\hline & Constant \& trend & -5.368 & 0.000 & -2.444 & 0.007 & -1.332 & 0.997 \\
\hline \multirow[t]{2}{*}{$\Delta$ NETINTERBANKCLAIMS } & Constant & -11.686 & 0.000 & -3.994 & 0.000 & -2.353 & 0.029 \\
\hline & Constant \& trend & -9.103 & 0.000 & -3.666 & 0.000 & -2.280 & 0.476 \\
\hline \multirow[t]{2}{*}{ NETINTERBANKLOANS } & Constant & -5.998 & 0.000 & -3.016 & 0.001 & -1.965 & 0.237 \\
\hline & Constant \& trend & -4.950 & 0.000 & -2.460 & 0.007 & -1.633 & 0.969 \\
\hline$\Delta$ NETINTERBANKLOANS & Constant & -11.267 & 0.000 & -4.561 & 0.000 & -2.598 & 0.004 \\
\hline & Constant \& trend & -8.952 & 0.000 & -3.748 & 0.000 & -2.377 & 0.363 \\
\hline
\end{tabular}

Table 5: Unit root tests: Credit pull and push factors (Notes: IPS is the Im-Pesaran-Shin unit-root test, and CADF is the Pesaran CADF test. The null hypothesis for all tests is that all panels contain unit roots. In the IPS and Breitung tests, the cross-sectional means are removed. In the CADF tests, the cross-sectional average is extracted in the first period and extreme t-values are truncated.) 


\begin{tabular}{|c|c|c|c|c|c|}
\hline \multirow[b]{2}{*}{ Variables } & \multirow[t]{2}{*}{ Kao } & \multicolumn{2}{|c|}{ Pedroni PP } & \multicolumn{2}{|c|}{ Pedroni ADF } \\
\hline & & Panel & Group & Panel & Group \\
\hline CA RELATIVEGDP REALEXRULC GOVBALANCE & $\begin{array}{l}-2.526 \\
(-0.006)\end{array}$ & $\begin{array}{l}-2.419 \\
(0.008)\end{array}$ & $\begin{array}{l}-5.462 \\
(0.000)\end{array}$ & $\begin{array}{l}-4.040 \\
(0.000)\end{array}$ & $\begin{array}{l}-4.950 \\
(0.000)\end{array}$ \\
\hline $\begin{array}{l}\text { CA RELATIVEGDP REALEXRULC GOVBALANCE } \\
\text { LIABILITIES }\end{array}$ & $\begin{array}{c}-3.574 \\
(0.000)\end{array}$ & $\begin{array}{l}-3.713 \\
(0.000)\end{array}$ & $\begin{array}{l}-5.121 \\
(0.000)\end{array}$ & $\begin{array}{l}-5.648 \\
(0.000)\end{array}$ & $\begin{array}{l}-5.541 \\
(0.000)\end{array}$ \\
\hline $\begin{array}{l}\text { CA RELATIVEGDP REALEXRULC GOVBALANCE } \\
\text { DEBT }\end{array}$ & $\begin{array}{l}-3.526 \\
(0.000)\end{array}$ & $\begin{array}{l}-3.282 \\
(0.001)\end{array}$ & $\begin{array}{l}-5.469 \\
(0.000)\end{array}$ & $\begin{array}{l}-4.079 \\
(0.000)\end{array}$ & $\begin{array}{l}-5.578 \\
(0.000)\end{array}$ \\
\hline $\begin{array}{l}\text { CA RELATIVEGDP REALEXRULC GOVBALANCE } \\
\text { LOANS }\end{array}$ & $\begin{array}{l}-3.491 \\
(0.000)\end{array}$ & $\begin{array}{l}-3.774 \\
(0.000)\end{array}$ & $\begin{array}{l}-5.962 \\
(0.000)\end{array}$ & $\begin{array}{l}-4.744 \\
(0.000)\end{array}$ & $\begin{array}{l}-6.000 \\
(0.000)\end{array}$ \\
\hline $\begin{array}{l}\text { CA RELATIVEGDP REALEXRULC GOVBALANCE } \\
\text { BANKLOANS }\end{array}$ & $\begin{array}{l}-3.583 \\
(0.000)\end{array}$ & $\begin{array}{l}-2.463 \\
(0.007)\end{array}$ & $\begin{array}{l}-3.526 \\
(0.000)\end{array}$ & $\begin{array}{l}-5.289 \\
(0.000)\end{array}$ & $\begin{array}{l}-5.626 \\
(0.000)\end{array}$ \\
\hline $\begin{array}{l}\text { CA RELATIVEGDP REALEXRULC GOVBALANCE } \\
\text { REALBANKLOANS }\end{array}$ & $\begin{array}{l}-4.061 \\
(0.000)\end{array}$ & $\begin{array}{l}-2.751 \\
(0.003)\end{array}$ & $\begin{array}{l}-4.550 \\
(0.000)\end{array}$ & $\begin{array}{l}-3.894 \\
(0.000)\end{array}$ & $\begin{array}{l}-5.034 \\
(0.000)\end{array}$ \\
\hline $\begin{array}{l}\text { CA RELATIVEGDP REALEXRULC GOVBALANCE } \\
\text { BANKCLAIMS }\end{array}$ & $\begin{array}{l}-3.024 \\
(0.001)\end{array}$ & $\begin{array}{l}-4.601 \\
(0.000)\end{array}$ & $\begin{array}{l}-7.360 \\
(0.000)\end{array}$ & $\begin{array}{l}-5.011 \\
(0.000)\end{array}$ & $\begin{array}{l}-6.370 \\
(0.000)\end{array}$ \\
\hline $\begin{array}{l}\text { CA RELATIVEGDP REALEXRULC GOVBALANCE } \\
\text { INTERBANKCLAIMS }\end{array}$ & $\begin{array}{l}-2.795 \\
(0.003)\end{array}$ & $\begin{array}{l}-5.170 \\
(0.000)\end{array}$ & $\begin{array}{c}-10.261 \\
(0.000)\end{array}$ & $\begin{array}{l}-5.285 \\
(0.000)\end{array}$ & $\begin{array}{l}-5.483 \\
(0.000)\end{array}$ \\
\hline $\begin{array}{l}\text { CA RELATIVEGDP REALEXRULC GOVBALANCE } \\
\text { NETBANKCLAIMS }\end{array}$ & $\begin{array}{l}-2.674 \\
(0.004)\end{array}$ & $\begin{array}{l}-2.801 \\
(0.003)\end{array}$ & $\begin{array}{l}-5.745 \\
(0.000)\end{array}$ & $\begin{array}{l}-3.459 \\
(0.000)\end{array}$ & $\begin{array}{l}-4.117 \\
(0.000)\end{array}$ \\
\hline $\begin{array}{l}\text { CA RELATIVEGDP REALEXRULC GOVBALANCE } \\
\text { NETINTERBANKCLAIMS }\end{array}$ & $\begin{array}{l}-2.468 \\
(0.007)\end{array}$ & $\begin{array}{l}-2.470 \\
(0.007)\end{array}$ & $\begin{array}{l}-3.843 \\
(0.000)\end{array}$ & $\begin{array}{l}-3.924 \\
(0.000)\end{array}$ & $\begin{array}{l}-4.180 \\
(0.000)\end{array}$ \\
\hline $\begin{array}{l}\text { CA RELATIVEGDP REALEXRULC GOVBALANCE } \\
\text { NETINTERBANKLOANS }\end{array}$ & $\begin{array}{l}-2.517 \\
(0.006)\end{array}$ & $\begin{array}{l}-0.599 \\
(0.275)\end{array}$ & $\begin{array}{l}-2.437 \\
(0.007)\end{array}$ & $\begin{array}{l}-2.906 \\
(0.000)\end{array}$ & $\begin{array}{l}-3.099 \\
(0.000)\end{array}$ \\
\hline $\begin{array}{l}\text { CA RELATIVEGDP REALEXRULC GOVBALANCE } \\
\text { REALBANKLOANS BANKCLAIMS }\end{array}$ & $\begin{array}{l}-4.120 \\
(0.000)\end{array}$ & $\begin{array}{l}-7.984 \\
(0.000)\end{array}$ & $\begin{array}{l}-1.176 \\
(0.000)\end{array}$ & $\begin{array}{l}-6.998 \\
(0.000)\end{array}$ & $\begin{array}{l}-6.883 \\
(0.000)\end{array}$ \\
\hline $\begin{array}{l}\text { CA REALEXRULC GOVBALANCE REALBANKLOANS } \\
\text { BANKCLAIMS }\end{array}$ & $\begin{array}{l}-4.196 \\
(0.000)\end{array}$ & $\begin{array}{l}-5.610 \\
(0.000)\end{array}$ & $\begin{array}{l}-6.710 \\
(0.000)\end{array}$ & $\begin{array}{l}-5.942 \\
(0.000)\end{array}$ & $\begin{array}{l}-6.398 \\
(0.000)\end{array}$ \\
\hline $\begin{array}{l}\text { CA REALEXRULC GOVBALANCE REALBANKLOANS } \\
\text { BANKCLAIMS DEPENDENCY }\end{array}$ & $\begin{array}{l}-4.161 \\
(0.000)\end{array}$ & $\begin{array}{l}-8.489 \\
(0.000)\end{array}$ & $\begin{array}{l}-1.427 \\
(0.000)\end{array}$ & $\begin{array}{l}-5.521 \\
(0.000)\end{array}$ & $\begin{array}{l}-5.892 \\
(0.000)\end{array}$ \\
\hline $\begin{array}{l}\text { CA REALEXRULC GOVBALANCE REALBANKLOANS } \\
\text { BANKCLAIMS POPULATION }\end{array}$ & $\begin{array}{l}-4.277 \\
(0.000)\end{array}$ & $\begin{array}{l}-6.294 \\
(0.000)\end{array}$ & $\begin{array}{l}-7.819 \\
(0.000)\end{array}$ & $\begin{array}{l}-5.450 \\
(0.000)\end{array}$ & $\begin{array}{l}-5.577 \\
(0.000)\end{array}$ \\
\hline $\begin{array}{l}\text { CA REALEXRULC GOVBALANCE REALBANKLOANS } \\
\text { BANKCLAIMS } N F A_{t-1}\end{array}$ & $\begin{array}{l}-5.158 \\
(0.000)\end{array}$ & $\begin{array}{l}-6.192 \\
(0.000)\end{array}$ & $\begin{array}{l}-8.992 \\
(0.000)\end{array}$ & $\begin{array}{l}-5.928 \\
(0.000)\end{array}$ & $\begin{array}{l}-5.318 \\
(0.000)\end{array}$ \\
\hline $\begin{array}{l}\text { CA REALEXRULC GOVBALANCE REALBANKLOANS } \\
\text { BANKCLAIMS HOUSEPRICE }\end{array}$ & $\begin{array}{l}-4.365 \\
(0.000)\end{array}$ & $\begin{array}{l}-4.287 \\
(0.000)\end{array}$ & $\begin{array}{l}-5.769 \\
(0.000)\end{array}$ & $\begin{array}{l}-4.550 \\
(0.000)\end{array}$ & $\begin{array}{l}-5.517 \\
(0.000)\end{array}$ \\
\hline $\begin{array}{l}\text { CA REALEXRULC GOVBALANCE REALBANKLOANS } \\
\text { BANKCLAIMS INTEREST }\end{array}$ & $\begin{array}{l}-4.919 \\
(0.000)\end{array}$ & $\begin{array}{l}-5.215 \\
(0.000)\end{array}$ & $\begin{array}{l}-8.902 \\
(0.000)\end{array}$ & $\begin{array}{l}-2.953 \\
(0.002)\end{array}$ & $\begin{array}{l}-3.806 \\
(0.000)\end{array}$ \\
\hline $\begin{array}{l}\text { CA REALEXRULC GOVBALANCE REALBANKLOANS } \\
\text { BANKCLAIMS DEPENDENCY HOUSEPRICE }\end{array}$ & $\begin{array}{l}-4.405 \\
(0.000)\end{array}$ & $\begin{array}{l}-4.873 \\
(0.000)\end{array}$ & $\begin{array}{r}-13.288 \\
(0.000)\end{array}$ & $\begin{array}{l}-2.873 \\
(0.002)\end{array}$ & $\begin{array}{l}-4.171 \\
(0.000)\end{array}$ \\
\hline $\begin{array}{l}\text { CA REALEXRULC GOVBALANCE REALBANKLOANS } \\
\text { BANKCLAIMS DEPENDENCY GOVBONDREAL }\end{array}$ & $\begin{array}{l}-5.012 \\
(0.000)\end{array}$ & $\begin{array}{l}-7.959 \\
(0.000)\end{array}$ & $\begin{array}{r}-15.242 \\
(0.000)\end{array}$ & $\begin{array}{l}-4.349 \\
(0.000)\end{array}$ & $\begin{array}{l}-5.309 \\
(0.000)\end{array}$ \\
\hline
\end{tabular}

Table 6: Cointegration tests (Notes: The table reports the t-statistic for the respective cointegration test. P-values are in parentheses. Kao is the Augmented Dickey-Fuller Kao residual cointegration test. Pedroni PP and AFD are the Phillips-Peron and Augmented Dickey-Fuller Pedroni residual cointegration tests. For all tests, the null hypothesis is of no cointegration. Lag length is automatically selected based on the BIC with a maximum lag length of 2 . The estimators use the Newey-West automatic bandwidth selection and a Bartlett kernel.) 


\section{Additional tables and robustness checks}

\begin{tabular}{|c|c|c|c|c|c|c|c|c|c|c|c|c|}
\hline \multirow[b]{2}{*}{ Variable } & \multicolumn{4}{|c|}{ deficit countries } & \multicolumn{4}{|c|}{ surplus countries } & \multicolumn{4}{|c|}{ other countries } \\
\hline & Mean & $\begin{array}{l}\text { Std. } \\
\text { Dev. }\end{array}$ & Min & Max & Mean & $\begin{array}{l}\text { Std. } \\
\text { Dev. }\end{array}$ & Min & Max & Mean & $\begin{array}{l}\text { Std. } \\
\text { Dev. }\end{array}$ & Min & Max \\
\hline LIABILITIES & 15.9 & 14.8 & -18.8 & 54.6 & 10.1 & 8.9 & -4.2 & 32.7 & 17.4 & 12.3 & -1.8 & 58.9 \\
\hline DEBT & 10.7 & 11.3 & -9.3 & 44.4 & 6.3 & 6.0 & -3.5 & 23.5 & 10.4 & 6.3 & -2.4 & 22.7 \\
\hline LOANS & 10.0 & 11.3 & -9.6 & 44.4 & 5.5 & 5.7 & -5.7 & 20.8 & 9.3 & 6.7 & -5.2 & 22.0 \\
\hline BANKLOANS & 6.6 & 10.0 & -2.1 & 31.3 & 3.4 & 3.2 & -1.2 & 12.2 & 3.7 & 3.0 & -4.8 & 9.1 \\
\hline REALBANKLOANS & 3.9 & 7.0 & -19.1 & 22.1 & 1.5 & 1.9 & -1.5 & 5.4 & 1.6 & 1.8 & -2.9 & 5.7 \\
\hline BANKCLAIMS & 2.5 & 9.4 & -21.4 & 35.4 & 1.7 & 3.9 & -6.3 & 9.1 & 2.0 & 8.4 & -20.7 & 21.5 \\
\hline INTERBANKCLAIMS & 1.3 & 5.5 & -11.8 & 16.4 & 0.7 & 3.2 & -6.4 & 9.0 & 1.0 & 6.7 & -19.6 & 18.0 \\
\hline NETBANKCLAIMS & 1.4 & 6.9 & -28.8 & 19.6 & 1.0 & 3.3 & -7.2 & 8.7 & 0.9 & 5.2 & -13.5 & 20.2 \\
\hline NETINTERBANKCLAIMS & 0.6 & 6.8 & -28.6 & 41.3 & 0.4 & 2.5 & -5.1 & 6.1 & 0.6 & 4.4 & -11.3 & 18.8 \\
\hline NETINTERBANKLOANS & -0.4 & 7.1 & -30.7 & 42.0 & 0.1 & 2.4 & -5.0 & 7.6 & 0.2 & 3.8 & -10.1 & 16.1 \\
\hline
\end{tabular}

Table 7: Descriptive statistics for the different credit pull and push factors (Notes: Deficit countries are Greece, Ireland, Italy, Portugal and Spain. Surplus countries are Austria, Germany and Netherlands. Other countries are Belgium, Finland and France.) 


\begin{tabular}{|c|c|c|c|c|c|c|c|c|c|c|}
\hline Variable & $\begin{array}{l}\mathrm{w} / \mathrm{o} \\
\mathrm{AT}\end{array}$ & $\begin{array}{l}\mathrm{w} / \mathrm{o} \\
\mathrm{DE}\end{array}$ & $\begin{array}{l}\mathrm{w} / \mathrm{o} \\
\mathrm{ES}\end{array}$ & $\begin{array}{c}\mathrm{w} / \mathrm{o} \\
\mathrm{FI}\end{array}$ & $\begin{array}{l}\text { w/o } \\
\text { FR }\end{array}$ & $\begin{array}{l}\text { w/o } \\
\text { GR }\end{array}$ & $\begin{array}{l}\mathrm{w} / \mathrm{o} \\
\mathrm{IE}\end{array}$ & $\begin{array}{l}\mathrm{w} / \mathrm{o} \\
\mathrm{IT}\end{array}$ & $\begin{array}{l}\mathrm{w} / \mathrm{o} \\
\mathrm{NL}\end{array}$ & $\begin{array}{l}\mathrm{w} / \mathrm{o} \\
\mathrm{PT}\end{array}$ \\
\hline$R E A L E X R U L C$ & $\begin{array}{l}-0.325^{* * *} \\
(0.015)\end{array}$ & $\begin{array}{l}-0.316^{* * *} \\
(0.015)\end{array}$ & $\begin{array}{l}-0.326^{* * *} \\
(0.015)\end{array}$ & $\begin{array}{l}-0.278^{* * *} \\
(0.066)\end{array}$ & $\begin{array}{l}-0.008 \\
(0.040)\end{array}$ & $\begin{array}{l}-0.314^{* * *} \\
(0.015)\end{array}$ & $\begin{array}{l}-0.320^{* * *} \\
(0.016)\end{array}$ & $\begin{array}{l}-0.318^{* * *} \\
(0.015)\end{array}$ & $\begin{array}{l}-0.318^{* * *} \\
(0.015)\end{array}$ & $\begin{array}{l}-0.320^{* * *} \\
(0.015)\end{array}$ \\
\hline GOVBALANCE & $\begin{array}{l}0.414^{* * *} \\
(0.018)\end{array}$ & $\begin{array}{l}0.424^{* * *} \\
(0.019)\end{array}$ & $\begin{array}{l}0.413^{* * *} \\
(0.018)\end{array}$ & $\begin{array}{l}0.412^{* * *} \\
(0.108)\end{array}$ & $\begin{array}{l}0.914^{* * *} \\
(0.025)\end{array}$ & $\begin{array}{l}0.427^{* * *} \\
(0.019)\end{array}$ & $\begin{array}{l}0.409^{* * *} \\
(0.019)\end{array}$ & $\begin{array}{l}0.422^{* * *} \\
(0.019)\end{array}$ & $\begin{array}{l}0.421^{* * *} \\
(0.019)\end{array}$ & $\begin{array}{c}0.420^{* * *} \\
(0.018)\end{array}$ \\
\hline PULLFACTOR & $\begin{array}{l}-0.383^{* * *} \\
(0.018)\end{array}$ & $\begin{array}{l}-0.393^{* * *} \\
(0.018)\end{array}$ & $\begin{array}{l}-0.383^{* * *} \\
(0.017)\end{array}$ & $\begin{array}{l}-1.057^{* * *} \\
(0.171)\end{array}$ & $\begin{array}{l}-1.011^{* * *} \\
(0.064)\end{array}$ & $\begin{array}{l}-0.397^{* * *} \\
(0.019)\end{array}$ & $\begin{array}{l}-0.378^{* * *} \\
(0.019)\end{array}$ & $\begin{array}{l}-0.392^{* * *} \\
(0.018)\end{array}$ & $\begin{array}{l}-0.390^{* * *} \\
(0.018)\end{array}$ & $\begin{array}{l}-0.388^{* * *} \\
(0.018)\end{array}$ \\
\hline PUSHF ACTOR & $\begin{array}{l}0.037^{* * *} \\
(0.012)\end{array}$ & $\begin{array}{l}0.038^{* * *} \\
(0.011)\end{array}$ & $\begin{array}{l}0.039^{* * *} \\
(0.011)\end{array}$ & $\begin{array}{l}-0.067^{* *} \\
(0.033)\end{array}$ & $\begin{array}{l}-0.067^{* *} \\
(0.030)\end{array}$ & $\begin{array}{l}0.040^{* * *} \\
(0.011)\end{array}$ & $\begin{array}{c}0.024 \\
(0.016)\end{array}$ & $\begin{array}{l}0.038^{* * *} \\
(0.011)\end{array}$ & $\begin{array}{l}0.037^{* * *} \\
(0.011)\end{array}$ & $\begin{array}{c}0.038^{* * *} \\
(0.011)\end{array}$ \\
\hline$D E P E N D E N C Y$ & $\begin{array}{l}-0.307^{* * *} \\
(0.061)\end{array}$ & $\begin{array}{l}-0.327^{* * *} \\
(0.060)\end{array}$ & $\begin{array}{l}-0.316^{* * *} \\
(0.059)\end{array}$ & $\begin{array}{c}0.890^{* * *} \\
(0.231)\end{array}$ & $\begin{array}{l}-0.025 \\
(0.144)\end{array}$ & $\begin{array}{l}-0.341^{* * *} \\
(0.060)\end{array}$ & $\begin{array}{l}-0.236^{* * *} \\
(0.085)\end{array}$ & $\begin{array}{l}-0.326^{* * *} \\
(0.059)\end{array}$ & $\begin{array}{l}-0.319^{* * *} \\
(0.060)\end{array}$ & $\begin{array}{l}-0.322^{* * *} \\
(0.059)\end{array}$ \\
\hline INTEREST & $\begin{array}{l}0.220^{\text {*** }} \\
(0.028)\end{array}$ & $\begin{array}{l}0.234^{* * *} \\
(0.028)\end{array}$ & $\begin{array}{l}0.225^{\text {*** }} \\
(0.027)\end{array}$ & $\begin{array}{c}0.568^{* * *} \\
(0.203)\end{array}$ & $\begin{array}{l}1.268^{* * *} \\
(0.115)\end{array}$ & $\begin{array}{l}0.240^{\text {*** }} \\
(0.028)\end{array}$ & $\begin{array}{l}0.200^{* * *} \\
(0.037)\end{array}$ & $\begin{array}{c}0.233^{* * *} \\
(0.028)\end{array}$ & $\begin{array}{l}0.230^{* * *} \\
(0.028)\end{array}$ & $\begin{array}{l}0.229^{* * *} \\
(0.028)\end{array}$ \\
\hline Error correction & $\begin{array}{l}-0.651^{* * *} \\
(0.138)\end{array}$ & $\begin{array}{l}-0.769^{* * *} \\
(0.140)\end{array}$ & $\begin{array}{l}-0.722^{\text {*** }} \\
(0.151)\end{array}$ & $\begin{array}{l}-0.317^{* * *} \\
(0.084)\end{array}$ & $\begin{array}{l}-0.499^{* *} \\
(0.204)\end{array}$ & $\begin{array}{l}-0.718^{* * *} \\
(0.154)\end{array}$ & $\begin{array}{l}-0.649^{* * *} \\
(0.132)\end{array}$ & $\begin{array}{l}-0.780^{\text {*** }} \\
(0.134)\end{array}$ & $\begin{array}{l}-0.740^{* * *} \\
(0.149)\end{array}$ & $\begin{array}{l}-0.714^{* * *} \\
(0.152)\end{array}$ \\
\hline Hausman test & $\begin{array}{c}0.000 \\
(1.000)\end{array}$ & $\begin{array}{c}0.000 \\
(1.000)\end{array}$ & $\begin{array}{c}0.000 \\
(1.000)\end{array}$ & $\begin{array}{c}0.000 \\
(1.000)\end{array}$ & $\begin{array}{c}0.000 \\
(1.000)\end{array}$ & $\begin{array}{c}0.000 \\
(1.000)\end{array}$ & $\begin{array}{c}0.000 \\
(1.000)\end{array}$ & $\begin{array}{c}0.000 \\
(1.000)\end{array}$ & $\begin{array}{c}0.000 \\
(1.000)\end{array}$ & $\begin{array}{c}0.000 \\
(1.000)\end{array}$ \\
\hline
\end{tabular}

Table 8: Pooled mean group estimates for current account as a percentage of GDP: best fit model II excluding one country at a time (Notes: The table reports the long-run coefficients for the respective variables. Standard errors are in parentheses. The column header indicates which country is excluded. PULLFACTOR corresponds to flows of bank loans to the domestic non-financial private sector excluding loans for house purchase. PUSHF ACTOR corresponds to flows of debt claims of domestic banks on debtors in other euro-area countries. Error correction shows the adjustment coefficient for deviations from the long-run equilibrium relation between the variables. Hausman test reports the chi2 test statistic and the corresponding p-value for systematic differences in coefficients of the PMG estimator vs. the MG estimator. $*, * *$ and $* * *$ denote significance at the 10,5 and $1 \%$ levels respectively.) 


\begin{tabular}{|c|c|c|c|c|c|c|c|c|c|c|}
\hline Variable & $\begin{array}{l}\text { LIABIL- } \\
\text { ITIES }\end{array}$ & DEBT & LOANS & $\begin{array}{l}\text { BANK- } \\
\text { LOANS }\end{array}$ & $\begin{array}{l}\text { REAL- } \\
\text { BANK- } \\
\text { LOANS }\end{array}$ & $\begin{array}{l}\text { BANK- } \\
\text { CLAIMS }\end{array}$ & $\begin{array}{l}\text { INTER- } \\
\text { BANK- } \\
\text { CLAIMS }\end{array}$ & $\begin{array}{c}\text { NET- } \\
\text { BANK- } \\
\text { CLAIMS }\end{array}$ & $\begin{array}{l}\text { NET- } \\
\text { INTER- } \\
\text { BANK- } \\
\text { CLAIMS }\end{array}$ & $\begin{array}{c}\text { NET- } \\
\text { INTER- } \\
\text { BANK- } \\
\text { LOANS }\end{array}$ \\
\hline CREDITPROXY & $\begin{array}{l}-0.104^{* * *} \\
(0.015)\end{array}$ & $\begin{array}{l}-0.273^{* * *} \\
(0.028)\end{array}$ & $\begin{array}{l}-0.321^{* * *} \\
(0.029)\end{array}$ & $\begin{array}{l}-0.368^{* * *} \\
(0.028)\end{array}$ & $\begin{array}{l}-0.548^{* * *} \\
(0.040)\end{array}$ & $\begin{array}{c}0.011 \\
(0.017)\end{array}$ & $\begin{array}{c}0.016 \\
(0.020)\end{array}$ & $\begin{array}{l}-0.044^{* * *} \\
(0.022)\end{array}$ & $\begin{array}{l}-0.155^{* * *} \\
(0.013)\end{array}$ & $\begin{array}{l}-0.078^{* *} \\
(0.033)\end{array}$ \\
\hline$R E A L E X R U L C$ & $\begin{array}{l}-0.290^{* * *} \\
(0.036)\end{array}$ & $\begin{array}{l}-0.248^{* * *} \\
(0.037)\end{array}$ & $\begin{array}{l}-0.133^{* * *} \\
(0.042)\end{array}$ & $\begin{array}{l}-0.181^{* * *} \\
(0.029)\end{array}$ & $\begin{array}{l}-0.194^{* * *} \\
(0.029)\end{array}$ & $\begin{array}{l}-0.360^{* * *} \\
(0.024)\end{array}$ & $\begin{array}{l}-0.358^{* * *} \\
(0.022)\end{array}$ & $\begin{array}{l}-0.372^{* * *} \\
(0.019)\end{array}$ & $\begin{array}{l}-0.570^{* * *} \\
(0.008)\end{array}$ & $\begin{array}{l}-0.355^{* * *} \\
(0.022)\end{array}$ \\
\hline$G O V B A L A N C E$ & $\begin{array}{l}-0.052 \\
(0.071)\end{array}$ & $\begin{array}{l}0.716^{* * *} \\
(0.078)\end{array}$ & $\begin{array}{l}0.740^{* * *} \\
(0.064)\end{array}$ & $\begin{array}{l}0.497^{* * *} \\
(0.037)\end{array}$ & $\begin{array}{l}0.621^{* * *} \\
(0.044)\end{array}$ & $\begin{array}{l}0.158^{* * *} \\
(0.057)\end{array}$ & $\begin{array}{l}0.253^{* * *} \\
(0.051)\end{array}$ & $\begin{array}{l}0.274^{* * *} \\
(0.049)\end{array}$ & $\begin{array}{l}-0.067^{* * *} \\
(0.012)\end{array}$ & $\begin{array}{c}0.221^{* * *} \\
(0.047)\end{array}$ \\
\hline$D E P E N D E N C Y$ & $\begin{array}{l}0.681^{* * *} \\
(0.166)\end{array}$ & $\begin{array}{l}-0.929^{* * *} \\
(0.215)\end{array}$ & $\begin{array}{l}-0.624^{* * *} \\
(0.150)\end{array}$ & $\begin{array}{l}-0.452^{* * *} \\
(0.111)\end{array}$ & $\begin{array}{l}-0.601^{* * *} \\
(0.105)\end{array}$ & $\begin{array}{l}0.401^{* * *} \\
(0.124)\end{array}$ & $\begin{array}{c}0.354^{* * *} \\
(0.116)\end{array}$ & $\begin{array}{l}0.236^{* * *} \\
(0.107)\end{array}$ & $\begin{array}{l}0.914^{* * *} \\
(0.063)\end{array}$ & $\begin{array}{l}0.278^{* * *} \\
(0.107)\end{array}$ \\
\hline INTEREST & $\begin{array}{l}-0.123 \\
(0.108)\end{array}$ & $\begin{array}{l}0.361^{* * *} \\
(0.064)\end{array}$ & $\begin{array}{c}0.024 \\
(0.042)\end{array}$ & $\begin{array}{c}0.052 \\
(0.037)\end{array}$ & $\begin{array}{l}0.288^{* * *} \\
(0.045)\end{array}$ & $\begin{array}{l}0.282^{* * *} \\
(0.062)\end{array}$ & $\begin{array}{l}0.252^{* * *} \\
(0.054)\end{array}$ & $\begin{array}{l}0.334^{* * *} \\
(0.047)\end{array}$ & $\begin{array}{l}-0.225^{* * *} \\
(0.021)\end{array}$ & $\begin{array}{l}0.264^{* * *} \\
(0.043)\end{array}$ \\
\hline Error correction & $\begin{array}{l}-0.494^{* * *} \\
(0.109)\end{array}$ & $\begin{array}{l}-0.548^{* * *} \\
(0.140)\end{array}$ & $\begin{array}{l}-0.569^{* * *} \\
(0.117)\end{array}$ & $\begin{array}{l}-0.696^{* * *} \\
(0.129)\end{array}$ & $\begin{array}{l}-0.728^{* * *} \\
(0.141)\end{array}$ & $\begin{array}{c}-0.632^{* * *} \\
(0.167)\end{array}$ & $\begin{array}{l}-0.573^{* * *} \\
(0.187)\end{array}$ & $\begin{array}{l}-0.610^{* * *} \\
(0.200)\end{array}$ & $\begin{array}{l}0.501^{* * *} \\
(0.139)\end{array}$ & $\begin{array}{l}-0.648^{* * *} \\
(0.211)\end{array}$ \\
\hline Hausman test & $\begin{array}{c}0.190 \\
(0.999)\end{array}$ & $\begin{array}{c}0.400 \\
(0.995)\end{array}$ & $\begin{array}{c}0.080 \\
(1.000)\end{array}$ & $\begin{array}{c}0.450 \\
(0.994)\end{array}$ & $\begin{array}{c}0.270 \\
(0.998)\end{array}$ & $\begin{array}{c}0.670 \\
(0.984)\end{array}$ & $\begin{array}{c}1.820 \\
(0.873)\end{array}$ & $\begin{array}{c}0.370 \\
(0.996)\end{array}$ & $\begin{array}{c}0.840 \\
(0.975)\end{array}$ & $\begin{array}{c}1.120 \\
(0.953)\end{array}$ \\
\hline
\end{tabular}

Table 9: Pooled mean group estimates for current account as a percentage of GDP: best fit model II augmented by various credit proxies (Notes: The table reports the long-run coefficients for the respective variables. Standard errors are in parentheses. CREDITPROXY is the push or pull factor as indicated in the column header. Error correction shows the adjustment coefficient for deviations from the long-run equilibrium relation between the variables. Hausman test reports the chi2 test statistic and the corresponding p-value for systematic differences in coefficients of the PMG estimator vs. the MG estimator. $*, * *$ and $* * *$ denote significance at the $10 \%, 5 \%$ and $1 \%$ levels respectively.) 


\begin{tabular}{|c|c|c|c|c|c|c|c|c|c|c|}
\hline Variable & $\begin{array}{l}\text { BANK- } \\
\text { CLAIMS }\end{array}$ & $\begin{array}{l}\text { INTER- } \\
\text { BANK- } \\
\text { CLAIMS }\end{array}$ & $\begin{array}{c}\text { NET- } \\
\text { BANK- } \\
\text { CLAIMS }\end{array}$ & $\begin{array}{l}\text { NET- } \\
\text { INTER- } \\
\text { BANK- } \\
\text { CLAIMS }\end{array}$ & $\begin{array}{l}\text { NET- } \\
\text { INTER- } \\
\text { BANK- } \\
\text { LOANS }\end{array}$ & $\begin{array}{l}\text { BANK- } \\
\text { CLAIMS }\end{array}$ & $\begin{array}{l}\text { INTER- } \\
\text { BANK- } \\
\text { CLAIMS }\end{array}$ & $\begin{array}{c}\text { NET- } \\
\text { BANK- } \\
\text { CLAIMS }\end{array}$ & $\begin{array}{l}\text { NET- } \\
\text { INTER- } \\
\text { BANK- } \\
\text { CLAIMS }\end{array}$ & $\begin{array}{c}\text { NET- } \\
\text { INTER- } \\
\text { BANK- } \\
\text { LOANS }\end{array}$ \\
\hline PUSHFACTOR & $\begin{array}{l}-0.218^{* * *} \\
(0.069)\end{array}$ & $\begin{array}{l}0.121^{* * *} \\
(0.039)\end{array}$ & $\begin{array}{l}0.088^{* * *} \\
(0.027)\end{array}$ & $\begin{array}{c}0.062^{*} \\
(0.032)\end{array}$ & $\begin{array}{l}-0.065^{*} \\
(0.039)\end{array}$ & $\begin{array}{c}0.007 \\
(0.032)\end{array}$ & $\begin{array}{c}0.079^{*} \\
(0.046)\end{array}$ & $\begin{array}{c}0.073 \\
(0.064)\end{array}$ & $\begin{array}{c}0.079 \\
(0.074)\end{array}$ & $\begin{array}{c}0.089 \\
(0.071)\end{array}$ \\
\hline RELATIVEGDP & $\begin{array}{l}-0.527^{* * *} \\
(0.143)\end{array}$ & $\begin{array}{l}-0.116^{* * *} \\
(0.041)\end{array}$ & $\begin{array}{l}0.130^{* * *} \\
(0.049)\end{array}$ & $\begin{array}{c}0.100^{* *} \\
(0.047)\end{array}$ & $\begin{array}{l}-0.102^{* *} \\
(0.052)\end{array}$ & & & & & \\
\hline$R E A L E X R U L C$ & $\begin{array}{l}-0.785^{* * *} \\
(0.073)\end{array}$ & $\begin{array}{l}-0.322^{* * *} \\
(0.037)\end{array}$ & $\begin{array}{l}-0.483^{* * *} \\
(0.033)\end{array}$ & $\begin{array}{l}-0.481^{* * *} \\
(0.034)\end{array}$ & $\begin{array}{l}-0.641^{* * *} \\
(0.041)\end{array}$ & $\begin{array}{l}-0.495^{* * *} \\
(0.021)\end{array}$ & $\begin{array}{l}-0.284^{* * *} \\
(0.074)\end{array}$ & $\begin{array}{l}-0.233^{* * *} \\
(0.091)\end{array}$ & $\begin{array}{l}-0.232^{* *} \\
(0.094)\end{array}$ & $\begin{array}{l}-0.228^{* *} \\
(0.097)\end{array}$ \\
\hline$G O V B A L A N C E$ & $\begin{array}{l}0.205^{* * *} \\
(0.054)\end{array}$ & $\begin{array}{l}-0.161 \\
(0.107)\end{array}$ & $\begin{array}{l}0.086^{* * *} \\
(0.028)\end{array}$ & $\begin{array}{c}0.138^{* * *} \\
(0.030)\end{array}$ & $\begin{array}{c}0.070^{* *} \\
(0.028)\end{array}$ & $\begin{array}{c}0.706^{* * *} \\
(0.072)\end{array}$ & $\begin{array}{l}0.425^{* * *} \\
(0.123)\end{array}$ & $\begin{array}{c}0.436^{* * *} \\
(0.089)\end{array}$ & $\begin{array}{l}-0.483^{* * *} \\
(0.115)\end{array}$ & $\begin{array}{c}0.501^{* * *} \\
(0.118)\end{array}$ \\
\hline PULLFACTOR & & & & & & $\begin{array}{l}-1.521^{* * *} \\
(0.129)\end{array}$ & $\begin{array}{l}-0.706^{* * *} \\
(0.191)\end{array}$ & $\begin{array}{l}-0.643^{* * *} \\
(0.160)\end{array}$ & $\begin{array}{l}-0.757^{* * *} \\
(0.167)\end{array}$ & $\begin{array}{l}-0.732^{* * *} \\
(0.168)\end{array}$ \\
\hline Error correction & $\begin{array}{l}-0.145^{* *} \\
(0.070)\end{array}$ & $\begin{array}{l}-0.427^{* * *} \\
(0.110)\end{array}$ & $\begin{array}{l}-0.435^{* * *} \\
(0.111)\end{array}$ & $\begin{array}{l}-0.417^{* * *} \\
(0.103)\end{array}$ & $\begin{array}{l}-0.331^{* * *} \\
(0.106)\end{array}$ & $\begin{array}{c}-0.381^{* * *} \\
(0.137)\end{array}$ & $\begin{array}{l}-1.050^{* * *} \\
(0.060)\end{array}$ & $\begin{array}{l}-0.973^{* * *} \\
(0.096)\end{array}$ & $\begin{array}{l}-0.885^{* * *} \\
(0.094)\end{array}$ & $\begin{array}{l}-0.857^{* * *} \\
(0.095)\end{array}$ \\
\hline Hausman test & $\begin{array}{l}1.180 \\
0.882\end{array}$ & $\begin{array}{l}0.640 \\
0.958\end{array}$ & $\begin{array}{l}2.640 \\
0.620\end{array}$ & $\begin{array}{l}1.480 \\
0.830\end{array}$ & $\begin{array}{l}0.720 \\
0.949\end{array}$ & $\begin{array}{l}4.000 \\
0.407\end{array}$ & $\begin{array}{c}15.070^{* * *} \\
0.005\end{array}$ & $\begin{array}{l}8.200^{* *} \\
0.084\end{array}$ & $\begin{array}{c}13.880^{* * *} \\
0.008\end{array}$ & $\begin{array}{c}97.110^{* * *} \\
0.000\end{array}$ \\
\hline
\end{tabular}

Table 10: Pooled mean group and mean group estimates for current account as a percentage of GDP: reference and baseline model II augmented by various credit push factors corrected for changes in TARGET2 balances (Notes: The table reports the long-run coefficients for the respective variables. Standard errors are in parentheses. PUSHFACTOR is the push factor as indicated in the column header. PULLFACTOR corresponds to flows of bank loans to the domestic non-financial private sector excluding loans for house purchase. Error correction shows the adjustment coefficient for deviations from the long-run equilibrium relation between the variables. Hausman test reports the chi2 test statistic and the corresponding p-value for systematic differences in coefficients of the PMG estimator vs. the MG estimator. When the Hausman test is rejected the model is estimated with the mean group estimator. $*, * *$ and $* * *$ denote significance at the $10 \%, 5 \%$ and $1 \%$ levels respectively.) 


\begin{tabular}{|c|c|c|c|c|c|c|c|c|c|c|}
\hline Variable & $\begin{array}{c}\text { Reference } \\
\text { model }\end{array}$ & $\begin{array}{c}\text { Baseline } \\
\text { model I }\end{array}$ & $\begin{array}{l}\text { Baseline } \\
\text { model II }\end{array}$ & $\begin{array}{c}\text { Extended } \\
\text { baseline } \\
\text { model I }\end{array}$ & $\begin{array}{c}\text { Extended } \\
\text { baseline } \\
\text { model II }\end{array}$ & $\begin{array}{c}\text { Extended } \\
\text { baseline } \\
\text { model III }\end{array}$ & $\begin{array}{c}\text { Extended } \\
\text { baseline } \\
\text { model IV }\end{array}$ & $\begin{array}{c}\text { Extended } \\
\text { baseline } \\
\text { model V }\end{array}$ & $\begin{array}{l}\text { Best fit } \\
\text { model I }\end{array}$ & $\begin{array}{l}\text { Best fit } \\
\text { model II }\end{array}$ \\
\hline RELATIVEGDP & $\begin{array}{l}-0.056 \\
(0.166)\end{array}$ & $\begin{array}{c}0.127 \\
(0.120)\end{array}$ & & & & & & & & \\
\hline$R E A L E X R U L C$ & $\begin{array}{l}-0.439^{* * *} \\
(0.091)\end{array}$ & $\begin{array}{l}-0.208 \\
(0.128)\end{array}$ & $\begin{array}{l}-0.152 \\
(0.147)\end{array}$ & $\begin{array}{l}-0.170 \\
(0.122)\end{array}$ & $\begin{array}{l}-0.172 \\
(0.156)\end{array}$ & $\begin{array}{l}-0.260^{* * *} \\
(0.105)\end{array}$ & $\begin{array}{l}-0.221 \\
(0.139)\end{array}$ & $\begin{array}{l}-0.168 \\
(0.117)\end{array}$ & $\begin{array}{l}-0.225^{* * *} \\
(0.091)\end{array}$ & $\begin{array}{l}-0.191^{* * *} \\
(0.083)\end{array}$ \\
\hline GOVBALANCE & $\begin{array}{l}-0.311^{* * *} \\
(0.086)\end{array}$ & $\begin{array}{c}0.460^{*} \\
(0.254)\end{array}$ & $\begin{array}{c}0.432 \\
(0.265)\end{array}$ & $\begin{array}{c}0.495^{*} \\
(0.272)\end{array}$ & $\begin{array}{c}0.448^{*} \\
(0.265)\end{array}$ & $\begin{array}{c}0.280^{* *} \\
(0.128)\end{array}$ & $\begin{array}{c}0.489^{* *} \\
(0.222)\end{array}$ & $\begin{array}{l}0.366^{* * *} \\
(0.236)\end{array}$ & $\begin{array}{l}0.505^{* * *} \\
(0.170)\end{array}$ & $\begin{array}{c}0.439^{* * *} \\
(0.161)\end{array}$ \\
\hline PULLFACTOR & & $\begin{array}{l}-0.765^{* * *} \\
(0.194)\end{array}$ & $\begin{array}{l}-0.789^{* * *} \\
(0.201)\end{array}$ & $\begin{array}{l}-0.782^{* * *} \\
(0.234)\end{array}$ & $\begin{array}{l}-0.788^{* * *} \\
(0.169)\end{array}$ & $\begin{array}{l}-0.551^{* * *} \\
(0.091)\end{array}$ & $\begin{array}{l}-0.632^{* * *} \\
(0.158)\end{array}$ & $\begin{array}{l}-0.648^{* * *} \\
(0.135)\end{array}$ & $\begin{array}{l}-0.640^{* * *} \\
(0.149)\end{array}$ & $\begin{array}{l}-0.624^{* * *} \\
(0.136)\end{array}$ \\
\hline PUSHFACTOR & & $\begin{array}{c}0.017 \\
(0.068)\end{array}$ & $\begin{array}{c}0.034 \\
(0.069)\end{array}$ & $\begin{array}{c}0.048 \\
(0.076)\end{array}$ & $\begin{array}{c}0.036 \\
(0.069)\end{array}$ & $\begin{array}{c}0.039 \\
(0.048)\end{array}$ & $\begin{array}{c}0.049 \\
(0.062)\end{array}$ & $\begin{array}{c}0.030 \\
(0.049)\end{array}$ & $\begin{array}{c}0.053 \\
(0.054)\end{array}$ & $\begin{array}{c}0.045 \\
(0.051)\end{array}$ \\
\hline$D E P E N D E N C Y$ & & & & $\begin{array}{c}0.088 \\
(0.338)\end{array}$ & & & & & $\begin{array}{l}-0.017 \\
(0.277)\end{array}$ & $\begin{array}{c}0.187 \\
(0.262)\end{array}$ \\
\hline POPULATION & & & & & $\begin{array}{c}0.317 \\
(1.031)\end{array}$ & & & & & \\
\hline$N F A_{t-1}$ & & & & & & $\begin{array}{l}-0.039^{* * *} \\
(0.011)\end{array}$ & & & & \\
\hline HOUSEPRICE & & & & & & & $\begin{array}{l}-0.195 \\
(0.130)\end{array}$ & & $\begin{array}{l}-0.187^{* *} \\
(0.091)\end{array}$ & \\
\hline INTEREST & & & & & & & & $\begin{array}{l}0.668^{* * *} \\
(0.149)\end{array}$ & & $\begin{array}{c}0.696^{* * *} \\
(0.186)\end{array}$ \\
\hline Error correction & $\begin{array}{l}-0.325^{* * *} \\
(0.124)\end{array}$ & $\begin{array}{l}-0.393^{* * *} \\
(0.108)\end{array}$ & $\begin{array}{l}-0.359^{* * *} \\
(0.116)\end{array}$ & $\begin{array}{l}-0.361^{* * *} \\
(0.112)\end{array}$ & $\begin{array}{l}-0.361^{* * *} \\
(0.116)\end{array}$ & $\begin{array}{l}-0.417^{* * *} \\
(0.113)\end{array}$ & $\begin{array}{l}-0.395^{* * *} \\
(0.118)\end{array}$ & $\begin{array}{l}-0.394^{* * *} \\
(0.112)\end{array}$ & $\begin{array}{l}-0.395^{* * *} \\
(0.071)\end{array}$ & $\begin{array}{l}-0.397^{* * *} \\
(0.067)\end{array}$ \\
\hline Hausman test & $\begin{array}{c}0.080 \\
(0.995)\end{array}$ & $\begin{array}{c}0.050 \\
(1.000)\end{array}$ & $\begin{array}{c}0.340 \\
(0.987)\end{array}$ & $\begin{array}{c}0.020 \\
(1.000)\end{array}$ & $\begin{array}{c}0.080 \\
(1.000)\end{array}$ & $\begin{array}{c}0.160 \\
(1.000)\end{array}$ & $\begin{array}{c}0.130 \\
(1.000)\end{array}$ & $\begin{array}{c}0.120 \\
(1.000)\end{array}$ & $\begin{array}{c}0.000 \\
(1.000)\end{array}$ & $\begin{array}{c}0.000 \\
(1.000)\end{array}$ \\
\hline
\end{tabular}

Table 11: Dynamic fixed effects estimates for current account as a percentage of GDP: baseline models and extensions (Notes: The table reports the long-run coefficients for the respective variables. Standard errors clustered at the country level are in parentheses. PULLFACTOR corresponds to flows of bank loans to the domestic non-financial private sector excluding loans for house purchase. PUSHFACTOR corresponds to flows of debt claims of domestic banks on debtors in other euro-area countries. Error correction shows the adjustment coefficient for deviations from the long-run equilibrium relation between the variables. Hausman test reports the chi2 test statistic and the corresponding p-value for systematic differences in coefficients of the DFE estimator vs. the MG estimator. *, ** and $* * *$ denote significance at the $10 \%, 5 \%$ and $1 \%$ levels respectively.) 


\begin{tabular}{|c|c|c|c|c|c|c|c|c|c|c|}
\hline Variable & $\begin{array}{c}\text { Reference } \\
\text { model }\end{array}$ & $\begin{array}{c}\text { Baseline } \\
\text { model I }\end{array}$ & $\begin{array}{l}\text { Baseline } \\
\text { model II }\end{array}$ & $\begin{array}{c}\text { Extended } \\
\text { baseline } \\
\text { model I }\end{array}$ & $\begin{array}{c}\text { Extended } \\
\text { baseline } \\
\text { model II }\end{array}$ & $\begin{array}{c}\text { Extended } \\
\text { baseline } \\
\text { model III }\end{array}$ & $\begin{array}{c}\text { Extended } \\
\text { baseline } \\
\text { model IV }\end{array}$ & $\begin{array}{c}\text { Extended } \\
\text { baseline } \\
\text { model V }\end{array}$ & $\begin{array}{l}\text { Best fit } \\
\text { model I }\end{array}$ & $\begin{array}{l}\text { Best fit } \\
\text { model II }\end{array}$ \\
\hline TREND & $\begin{array}{c}0.363 \\
(0.225)\end{array}$ & $\begin{array}{c}0.345^{* *} \\
(0.147)\end{array}$ & $\begin{array}{c}0.387^{* *} \\
(0.171)\end{array}$ & $\begin{array}{c}0.377^{* *} \\
(0.161)\end{array}$ & $\begin{array}{c}0.380^{* *} \\
(0.177)\end{array}$ & $\begin{array}{l}0.378^{* * *} \\
(0.146)\end{array}$ & $\begin{array}{c}0.352^{* *} \\
(0.142)\end{array}$ & $\begin{array}{c}0.438^{* *} \\
(0.173)\end{array}$ & $\begin{array}{l}0.394^{* * *} \\
(0.135)\end{array}$ & $\begin{array}{l}0.398^{* * *} \\
(0.147)\end{array}$ \\
\hline$B R E A K$ & $\begin{array}{l}-2.174 \\
(1.575)\end{array}$ & $\begin{array}{l}-3.026^{* *} \\
(1.216)\end{array}$ & $\begin{array}{l}-3.251^{* * *} \\
(1.240)\end{array}$ & $\begin{array}{l}-3.168^{* * *} \\
(1.167)\end{array}$ & $\begin{array}{l}-3.154^{* * *} \\
(1.218)\end{array}$ & $\begin{array}{l}-2.843^{* * *} \\
(1.055)\end{array}$ & $\begin{array}{l}-3.510^{* * *} \\
(0.993)\end{array}$ & $\begin{array}{l}-3.571^{* * *} \\
(1.066)\end{array}$ & $\begin{array}{l}-3.529^{* * *} \\
(1.012)\end{array}$ & $\begin{array}{l}-3.500^{* * *} \\
(1.064)\end{array}$ \\
\hline RELATIVEGDP & $\begin{array}{l}-0.091 \\
(0.144)\end{array}$ & $\begin{array}{c}0.098 \\
(0.091)\end{array}$ & & & & & & & & \\
\hline$R E A L E X R U L C$ & $\begin{array}{l}-0.451^{* * *} \\
(0.090)\end{array}$ & $\begin{array}{l}-0.243^{*} \\
(0.128)\end{array}$ & $\begin{array}{l}-0.199 \\
(0.144)\end{array}$ & $\begin{array}{l}-0.209 \\
(0.130)\end{array}$ & $\begin{array}{l}-0.207 \\
(0.148)\end{array}$ & $\begin{array}{l}-0.303^{* * *} \\
(0.105)\end{array}$ & $\begin{array}{l}-0.277^{* *} \\
(0.129)\end{array}$ & $\begin{array}{c}-0.216^{*} \\
(0.116)\end{array}$ & $\begin{array}{c}-0.284^{* *} \\
(0.127)\end{array}$ & $\begin{array}{l}-0.224^{* *} \\
(0.099)\end{array}$ \\
\hline GOVBALANCE & $\begin{array}{l}-0.244^{* * *} \\
(0.095)\end{array}$ & $\begin{array}{r}0.422^{*} \\
(0.232)\end{array}$ & $\begin{array}{c}0.406^{*} \\
(0.240)\end{array}$ & $\begin{array}{r}0.435^{*} \\
(0.256)\end{array}$ & $\begin{array}{r}0.418^{*} \\
(0.242)\end{array}$ & $\begin{array}{c}0.346 \\
(0.103)\end{array}$ & $\begin{array}{l}0.275^{* * *} \\
(0.197)\end{array}$ & $\begin{array}{l}0.440^{* *} \\
(0.212)\end{array}$ & $\begin{array}{c}0.436^{* *} \\
(0.1959\end{array}$ & $\begin{array}{c}0.371 \\
(0.236)\end{array}$ \\
\hline PULLFACTOR & & $\begin{array}{l}-0.719^{* * *} \\
(0.200)\end{array}$ & $\begin{array}{l}-0.738^{* * *} \\
(0.203)\end{array}$ & $\begin{array}{l}-0.747^{* * *} \\
(0.224)\end{array}$ & $\begin{array}{l}-0.728^{* * *} \\
(0.182)\end{array}$ & $\begin{array}{l}-0.507^{* * *} \\
(0.060)\end{array}$ & $\begin{array}{l}-0.584^{* * *} \\
(0.140)\end{array}$ & $\begin{array}{l}-0.589^{* * *} \\
(0.143)\end{array}$ & $\begin{array}{l}-0.588^{* * *} \\
(0.140)\end{array}$ & $\begin{array}{l}-0.588^{* * *} \\
(0.153)\end{array}$ \\
\hline PUSHFACTOR & & $\begin{array}{l}-0.006 \\
(0.061)\end{array}$ & $\begin{array}{c}0.009 \\
(0.065)\end{array}$ & $\begin{array}{c}0.016 \\
(0.070)\end{array}$ & $\begin{array}{c}0.011 \\
(0.063)\end{array}$ & $\begin{array}{c}0.021 \\
(0.043)\end{array}$ & $\begin{array}{c}0.013 \\
(0.053)\end{array}$ & $\begin{array}{c}0.004 \\
(0.033)\end{array}$ & $\begin{array}{c}0.015 \\
(0.055)\end{array}$ & $\begin{array}{c}0.009 \\
(0.035)\end{array}$ \\
\hline$D E P E N D E N C Y$ & & & & $\begin{array}{l}-0.059 \\
(0.336)\end{array}$ & & & & & $\begin{array}{l}-0.156 \\
(0.280)\end{array}$ & $\begin{array}{c}0.063 \\
(0.304)\end{array}$ \\
\hline POPULATION & & & & & $\begin{array}{c}0.035 \\
(0.902)\end{array}$ & & & & & \\
\hline$N F A_{t-1}$ & & & & & & $\begin{array}{l}-0.038^{* * *} \\
(0.009)\end{array}$ & & & & \\
\hline HOUSEPRICE & & & & & & & $\begin{array}{l}-0.216 \\
(0.112)\end{array}$ & & $\begin{array}{l}-0.225^{* *} \\
(0.106)\end{array}$ & \\
\hline INTEREST & & & & & & & & $\begin{array}{l}0.666^{* * *} \\
(0.134)\end{array}$ & & $\begin{array}{c}0.674^{* * *} \\
(0.134)\end{array}$ \\
\hline Error correction & $\begin{array}{l}-0.348^{* * *} \\
(0.135)\end{array}$ & $\begin{array}{l}-0.435^{* * *} \\
(0.100)\end{array}$ & $\begin{array}{l}-0.404^{* * *} \\
(0.113)\end{array}$ & $\begin{array}{l}-0.405^{* * *} \\
(0.111)\end{array}$ & $\begin{array}{l}-0.405^{\text {*** }} \\
(0.112)\end{array}$ & $\begin{array}{l}-0.468^{* * *} \\
(0.097)\end{array}$ & $\begin{array}{l}-0.456^{* * *} \\
(0.100)\end{array}$ & $\begin{array}{l}-0.447^{* * *} \\
(0.121)\end{array}$ & $\begin{array}{l}-0.451^{* * *} \\
(0.123)\end{array}$ & $\begin{array}{l}-0.456^{* * *} \\
(0.101)\end{array}$ \\
\hline Hausman test & $\begin{array}{c}0.550 \\
(0.990)\end{array}$ & $\begin{array}{c}0.000 \\
(1.000)\end{array}$ & $\begin{array}{c}0.220 \\
(1.000)\end{array}$ & $\begin{array}{c}0.000 \\
(1.000)\end{array}$ & $\begin{array}{c}0.000 \\
(1.000)\end{array}$ & $\begin{array}{c}0.000 \\
(1.000)\end{array}$ & $\begin{array}{c}0.000 \\
(1.000)\end{array}$ & $\begin{array}{c}0.000 \\
(1.000)\end{array}$ & $\begin{array}{c}0.000 \\
(1.000)\end{array}$ & $\begin{array}{c}0.000 \\
(1.000)\end{array}$ \\
\hline
\end{tabular}

Table 12: Dynamic fixed effects estimates for current account as a percentage of GDP including a linear time trend and a structural break dummy: baseline models and extensions (Notes: The table reports the long-run coefficients for the respective variables. Standard errors clustered at the country level are in parentheses. PULLFACTOR corresponds to flows of bank loans to the domestic non-financial private sector excluding loans for house purchase. PUSHFACTOR corresponds to flows of debt claims of domestic banks on debtors in other euro-area countries. Error correction shows the adjustment coefficient for deviations from the long-run equilibrium relation between the variables. TREND is a linear time trend. BREAK is a dummy variable set to one from the beginning of the adjustment period in 2008 and zero otherwise. Hausman test reports the chi2 test statistic and the corresponding p-value for systematic differences in coefficients of the DFE estimator vs. the MG estimator. $*, * *$ and $* * *$ denote significance at the $10 \%, 5 \%$ and $1 \%$ levels respectively.) 


\begin{tabular}{|c|c|c|c|c|c|c|c|c|c|c|}
\hline Model & $\begin{array}{c}\text { Reference } \\
\text { model }\end{array}$ & $\begin{array}{c}\text { Baseline } \\
\text { model I }\end{array}$ & $\begin{array}{l}\text { Baseline } \\
\text { model II }\end{array}$ & $\begin{array}{c}\text { Extended } \\
\text { baseline } \\
\text { model I }\end{array}$ & $\begin{array}{c}\text { Extended } \\
\text { baseline } \\
\text { model II }\end{array}$ & $\begin{array}{c}\text { Extended } \\
\text { baseline } \\
\text { model III }\end{array}$ & $\begin{array}{c}\text { Extended } \\
\text { baseline } \\
\text { model IV }\end{array}$ & $\begin{array}{c}\text { Extended } \\
\text { baseline } \\
\text { model V }\end{array}$ & $\begin{array}{l}\text { Best fit } \\
\text { model I }\end{array}$ & $\begin{array}{l}\text { Best fit } \\
\text { model II }\end{array}$ \\
\hline RELATIVEGDP & $\begin{array}{l}-0.044 \\
(0.099)\end{array}$ & $\begin{array}{l}-0.006 \\
(0.101)\end{array}$ & & & & & & & & \\
\hline$R E A L E X R U L C$ & $\begin{array}{l}-0.468^{* * *} \\
(0.085)\end{array}$ & $\begin{array}{l}-0.342^{* *} \\
(0.140)\end{array}$ & $\begin{array}{c}-0.293^{*} \\
(0.157)\end{array}$ & $\begin{array}{c}-0.293^{* *} \\
(0.120)\end{array}$ & $\begin{array}{l}-0.306 \\
(0.211)\end{array}$ & $\begin{array}{l}-0.404^{* * *} \\
(0.084)\end{array}$ & $\begin{array}{l}-0.251 \\
(0.194)\end{array}$ & $\begin{array}{c}-0.284^{* *} \\
(0.137)\end{array}$ & $\begin{array}{c}-0.285^{* *} \\
(0.143)\end{array}$ & $\begin{array}{l}-0.284^{* *} \\
(0.114)\end{array}$ \\
\hline$G O V B A L A N C E$ & $\begin{array}{l}-0.328^{* * *} \\
0.116\end{array}$ & $\begin{array}{l}0.128 \\
0.329\end{array}$ & $\begin{array}{l}0.117 \\
0.312\end{array}$ & $\begin{array}{l}0.180 \\
0.286\end{array}$ & $\begin{array}{l}0.076 \\
0.339\end{array}$ & $\begin{array}{r}-0.039 \\
0.235\end{array}$ & $\begin{array}{l}0.098 \\
0.348\end{array}$ & $\begin{array}{r}-0.008 \\
0.256\end{array}$ & $\begin{array}{l}0.194 \\
0.309\end{array}$ & $\begin{array}{l}0.154 \\
0.256\end{array}$ \\
\hline PULLF ACTOR & & $\begin{array}{l}-0.413^{* * *} \\
(0.154)\end{array}$ & $\begin{array}{l}-0.459^{* *} \\
(0.184)\end{array}$ & $\begin{array}{l}-0.455^{* * *} \\
(0.169)\end{array}$ & $\begin{array}{l}-0.491^{* *} \\
(0.206)\end{array}$ & $\begin{array}{l}-0.275^{\text {*** }} \\
(0.105)\end{array}$ & $\begin{array}{c}-0.489^{* *} \\
(0.204)\end{array}$ & $\begin{array}{c}-0.396^{* *} \\
(0.181)\end{array}$ & $\begin{array}{c}-0.478^{* *} \\
(0.199)\end{array}$ & $\begin{array}{l}-0.376^{* *} \\
(0.152)\end{array}$ \\
\hline PUSHFACTOR & & $\begin{array}{c}0.028 \\
(0.078)\end{array}$ & $\begin{array}{c}0.052 \\
(0.073)\end{array}$ & $\begin{array}{c}0.043 \\
(0.069)\end{array}$ & $\begin{array}{c}0.071 \\
(0.074)\end{array}$ & $\begin{array}{c}0.056 \\
(0.056)\end{array}$ & $\begin{array}{c}0.069 \\
(0.090)\end{array}$ & $\begin{array}{c}0.067 \\
(0.069)\end{array}$ & $\begin{array}{c}0.059 \\
(0.089)\end{array}$ & $\begin{array}{c}0.040 \\
(0.065)\end{array}$ \\
\hline DEPENDENCY & & & & $\begin{array}{l}-0.267 \\
(0.279)\end{array}$ & & & & & $\begin{array}{l}-0.350 \\
(0.349)\end{array}$ & $\begin{array}{c}0.022 \\
(0.289)\end{array}$ \\
\hline POPULATION & & & & & $\begin{array}{c}0.303 \\
(1.947)\end{array}$ & & & & & \\
\hline$N F A_{t-1}$ & & & & & & $\begin{array}{l}-0.027^{*} \\
(0.015)\end{array}$ & & & & \\
\hline HOUSEPRICE & & & & & & & $\begin{array}{c}0.049 \\
(0.064)\end{array}$ & & $\begin{array}{l}-0.033 \\
(0.092)\end{array}$ & \\
\hline INTEREST & & & & & & & & $\begin{array}{l}1.237^{* * *} \\
(0.149)\end{array}$ & & $\begin{array}{c}1.039^{* *} \\
(0.186)\end{array}$ \\
\hline Error correction & $\begin{array}{l}-0.566^{* * *} \\
(0.152)\end{array}$ & $\begin{array}{l}-0.484^{* * *} \\
(0.152)\end{array}$ & $\begin{array}{l}-0.449^{* * *} \\
(0.131)\end{array}$ & $\begin{array}{l}-0.531^{* * *} \\
(0.196)\end{array}$ & $\begin{array}{l}-0.435^{* * *} \\
(0.128)\end{array}$ & $\begin{array}{l}-0.570^{* * *} \\
(0.108)\end{array}$ & $\begin{array}{l}-0.386^{* * *} \\
(0.129)\end{array}$ & $\begin{array}{l}-0.458^{* * *} \\
(0.116)\end{array}$ & $\begin{array}{l}-0.457^{* *} \\
(0.194)\end{array}$ & $\begin{array}{l}-0.554^{* * *} \\
(0.190)\end{array}$ \\
\hline
\end{tabular}

Table 13: Dynamic fixed effects estimates for current account as a percentage of GDP including two lagged differences: baseline models and extensions (Notes: The table reports the long-run coefficients for the respective variables. Standard errors clustered at the time level are in parentheses. PULLFACTOR corresponds to flows of bank loans to the domestic non-financial private sector excluding loans for house purchase. PUSHFACTOR corresponds to flows of debt claims of domestic banks on debtors in other euro-area countries. Error correction shows the adjustment coefficient for deviations from the long-run equilibrium relation between the variables. $*, * *$ and $* * *$ denote significance at the $10 \%, 5 \%$ and $1 \%$ levels respectively.) 


\begin{tabular}{|c|c|c|c|c|c|c|c|c|c|c|}
\hline Model & $\begin{array}{c}\text { Reference } \\
\text { model }\end{array}$ & $\begin{array}{c}\text { Baseline } \\
\text { model I }\end{array}$ & $\begin{array}{l}\text { Baseline } \\
\text { model II }\end{array}$ & $\begin{array}{c}\text { Extended } \\
\text { baseline } \\
\text { model I }\end{array}$ & $\begin{array}{c}\text { Extended } \\
\text { baseline } \\
\text { model II }\end{array}$ & $\begin{array}{l}\text { Extended } \\
\text { baseline } \\
\text { model III }\end{array}$ & $\begin{array}{c}\text { Extended } \\
\text { baseline } \\
\text { model IV }\end{array}$ & $\begin{array}{c}\text { Extended } \\
\text { baseline } \\
\text { model V }\end{array}$ & $\begin{array}{l}\text { Best fit } \\
\text { model I }\end{array}$ & $\begin{array}{l}\text { Best fit } \\
\text { model II }\end{array}$ \\
\hline RELATIVEGDP & $\begin{array}{l}-0.060 \\
(0.140)\end{array}$ & $\begin{array}{l}-0.069 \\
(0.090)\end{array}$ & & & & & & & & \\
\hline$R E A L E X R U L C$ & $\begin{array}{l}-0.367^{* * *} \\
(0.079)\end{array}$ & $\begin{array}{l}-0.249^{*} \\
(0.147)\end{array}$ & $\begin{array}{l}-0.192 \\
(0.161)\end{array}$ & $\begin{array}{l}-0.199 \\
(0.148)\end{array}$ & $\begin{array}{l}-0.195 \\
(0.157)\end{array}$ & $\begin{array}{l}-0.330^{* * *} \\
(0.114)\end{array}$ & $\begin{array}{l}-0.290^{*} \\
(0.149)\end{array}$ & $\begin{array}{l}-0.222^{*} \\
(0.128)\end{array}$ & $\begin{array}{l}-0.298^{* *} \\
(0.150)\end{array}$ & $\begin{array}{l}-0.223^{* *} \\
(0.113)\end{array}$ \\
\hline GOVBALANCE & $\begin{array}{l}-0.261^{* * *} \\
(0.100)\end{array}$ & $\begin{array}{c}0.347 \\
(0.309)\end{array}$ & $\begin{array}{c}0.333 \\
(0.318)\end{array}$ & $\begin{array}{c}0.342 \\
(0.313)\end{array}$ & $\begin{array}{c}0.343 \\
(0.324)\end{array}$ & $\begin{array}{c}0.142 \\
(0.137)\end{array}$ & $\begin{array}{c}0.429 \\
(0.266)\end{array}$ & $\begin{array}{c}0.269 \\
(0.233)\end{array}$ & $\begin{array}{c}0.362 \\
(0.243)\end{array}$ & $\begin{array}{c}0.315 \\
(0.258)\end{array}$ \\
\hline PULLFACTOR & & $\begin{array}{l}-0.659^{* *} \\
(0.319)\end{array}$ & $\begin{array}{l}-0.692^{* *} \\
(0.311)\end{array}$ & $\begin{array}{l}-0.702^{* *} \\
(0.325)\end{array}$ & $\begin{array}{l}-0.656^{* *} \\
(0.334)\end{array}$ & $\begin{array}{l}-0.345^{* * *} \\
(0.129)\end{array}$ & $\begin{array}{l}-0.555^{* *} \\
(0.246)\end{array}$ & $\begin{array}{l}-0.494^{* *} \\
(0.204)\end{array}$ & $\begin{array}{l}-0.527^{* *} \\
(0.249)\end{array}$ & $\begin{array}{l}-0.506^{* *} \\
(0.216)\end{array}$ \\
\hline PUSHFACTOR & & $\begin{array}{c}0.011 \\
(0.066)\end{array}$ & $\begin{array}{c}0.029 \\
(0.075)\end{array}$ & $\begin{array}{c}0.034 \\
(0.072)\end{array}$ & $\begin{array}{c}0.031 \\
(0.070)\end{array}$ & $\begin{array}{c}0.051 \\
(0.052)\end{array}$ & $\begin{array}{c}0.019 \\
(0.060)\end{array}$ & $\begin{array}{c}0.011 \\
(0.029)\end{array}$ & $\begin{array}{c}0.026 \\
(0.058)\end{array}$ & $\begin{array}{c}0.007 \\
(0.026)\end{array}$ \\
\hline DEPENDENCY & & & & $\begin{array}{l}-0.122 \\
(0.464)\end{array}$ & & & & & $\begin{array}{l}-0.235 \\
(0.393)\end{array}$ & $\begin{array}{c}0.125 \\
(0.336)\end{array}$ \\
\hline POPULATION & & & & & $\begin{array}{l}-0.295 \\
(1.068)\end{array}$ & & & & & \\
\hline$N F A_{t-1}$ & & & & & & $\begin{array}{l}-0.050^{*} \\
(0.008)\end{array}$ & & & & \\
\hline HOUSEPRICE & & & & & & & $\begin{array}{c}0.243^{* *} \\
(0.138)\end{array}$ & & $\begin{array}{c}-0.261^{*} \\
(0.143)\end{array}$ & \\
\hline INTEREST & & & & & & & & $\begin{array}{l}0.795^{* * *} \\
(0.178)\end{array}$ & & $\begin{array}{l}0.7979^{* * *} \\
(0.180)\end{array}$ \\
\hline Error correction & $\begin{array}{l}-0.308^{* * *} \\
(0.148)\end{array}$ & $\begin{array}{l}-0.370^{* * *} \\
(0.106)\end{array}$ & $\begin{array}{l}-0.340^{* * *} \\
(0.114)\end{array}$ & $\begin{array}{l}-0.340^{* * *} \\
(0.113)\end{array}$ & $\begin{array}{l}-0.342^{* * *} \\
(0.119)\end{array}$ & $\begin{array}{l}-0.402^{* * *} \\
(0.091)\end{array}$ & $\begin{array}{l}-0.383^{* * *} \\
(0.125)\end{array}$ & $\begin{array}{l}-0.405^{* * *} \\
(0.107)\end{array}$ & $\begin{array}{l}-0.381^{\text {*** }} \\
(0.126)\end{array}$ & $\begin{array}{l}-0.409^{* * *} \\
(0.108)\end{array}$ \\
\hline
\end{tabular}

Table 14: Dynamic fixed effects estimates for current account as a percentage of GDP including cross-sectional averages: baseline models and extensions (Notes: The table reports the long-run coefficients for the respective variables. Standard errors clustered at the country level are in parentheses. PULLFACTOR corresponds to flows of bank loans to the domestic non-financial private sector excluding loans for house purchase. PUSHFACTOR corresponds to flows of debt claims of domestic banks on debtors in other euro-area countries. Error correction shows the adjustment coefficient for deviations from the long-run equilibrium relation between the variables. $*, * *$ and $* * *$ denote significance at the $10 \%, 5 \%$ and $1 \%$ levels respectively.) 


\begin{tabular}{|c|c|c|c|c|c|c|c|c|c|c|}
\hline Model & $\begin{array}{c}\text { Reference } \\
\text { model }\end{array}$ & $\begin{array}{c}\text { Baseline } \\
\text { model I }\end{array}$ & $\begin{array}{l}\text { Baseline } \\
\text { model II }\end{array}$ & $\begin{array}{c}\text { Extended } \\
\text { baseline } \\
\text { model I }\end{array}$ & $\begin{array}{c}\text { Extended } \\
\text { baseline } \\
\text { model II }\end{array}$ & $\begin{array}{c}\text { Extended } \\
\text { baseline } \\
\text { model III }\end{array}$ & $\begin{array}{c}\text { Extended } \\
\text { baseline } \\
\text { model IV }\end{array}$ & $\begin{array}{c}\text { Extended } \\
\text { baseline } \\
\text { model V }\end{array}$ & $\begin{array}{l}\text { Best fit } \\
\text { model I }\end{array}$ & $\begin{array}{l}\text { Best fit } \\
\text { model II }\end{array}$ \\
\hline RELATIVEGDP & $\begin{array}{l}-0.108 \\
(0.094)\end{array}$ & $\begin{array}{c}0.035 \\
(0.087)\end{array}$ & & & & & & & & \\
\hline$R E A L E X R U L C$ & $\begin{array}{l}-0.368^{* * *} \\
(0.078)\end{array}$ & $\begin{array}{l}-0.265^{* * *} \\
(0.079)\end{array}$ & $\begin{array}{l}-0.262^{* * *} \\
(0.083)\end{array}$ & $\begin{array}{l}-0.262^{* * *} \\
(0.082)\end{array}$ & $\begin{array}{l}-0.238^{* *} \\
(0.101)\end{array}$ & $\begin{array}{l}-0.301^{* * *} \\
(0.078)\end{array}$ & $\begin{array}{l}-0.289^{* * *} \\
(0.084)\end{array}$ & $\begin{array}{l}-0.262^{* * *} \\
(0.083)\end{array}$ & $\begin{array}{l}-0.292^{* * *} \\
(0.079)\end{array}$ & $\begin{array}{l}-0.261^{* * *} \\
(0.080)\end{array}$ \\
\hline GOVBALANCE & $\begin{array}{l}-0.139 \\
(0.078)\end{array}$ & $\begin{array}{l}0.304^{* * *} \\
(0.094)\end{array}$ & $\begin{array}{c}0.296^{* *} \\
(0.104)\end{array}$ & $\begin{array}{c}0.296^{* *} \\
(0.104)\end{array}$ & $\begin{array}{c}0.294^{* *} \\
(0.105)\end{array}$ & $\begin{array}{c}0.244^{* *} \\
(0.085)\end{array}$ & $\begin{array}{c}0.307^{* *} \\
(0.106)\end{array}$ & $\begin{array}{c}0.285^{* *} \\
(0.094)\end{array}$ & $\begin{array}{c}0.308^{* *} \\
(0.103)\end{array}$ & $\begin{array}{c}0.285^{* *} \\
(0.098)\end{array}$ \\
\hline PULLFACTOR & & $\begin{array}{l}-0.423^{* * *} \\
(0.068)\end{array}$ & $\begin{array}{l}-0.407^{* * *} \\
(0.085)\end{array}$ & $\begin{array}{l}-0.408^{* * *} \\
(0.097)\end{array}$ & $\begin{array}{l}-0.363^{* * *} \\
(0.092)\end{array}$ & $\begin{array}{l}-0.324^{* * *} \\
(0.099)\end{array}$ & $\begin{array}{l}-0.372^{* * *} \\
(0.083)\end{array}$ & $\begin{array}{l}-0.346^{* * *} \\
(0.080)\end{array}$ & $\begin{array}{l}-0.376^{* * *} \\
(0.092)\end{array}$ & $\begin{array}{l}-0.338^{* * *} \\
(0.089)\end{array}$ \\
\hline PUSHFACTOR & & $\begin{array}{l}-0.016 \\
(0.044)\end{array}$ & $\begin{array}{l}-0.015 \\
(0.043)\end{array}$ & $\begin{array}{l}-0.015 \\
(0.043)\end{array}$ & $\begin{array}{l}-0.013 \\
(0.038)\end{array}$ & $\begin{array}{l}-0.005 \\
(0.030)\end{array}$ & $\begin{array}{l}-0.009 \\
(0.042)\end{array}$ & $\begin{array}{l}-0.019 \\
(0.041)\end{array}$ & $\begin{array}{l}-0.009 \\
(0.043)\end{array}$ & $\begin{array}{l}-0.019 \\
(0.041)\end{array}$ \\
\hline$D E P E N D E N C Y$ & & & & $\begin{array}{l}-0.004 \\
(0.252)\end{array}$ & & & & & $\begin{array}{l}-0.058 \\
(0.251)\end{array}$ & $\begin{array}{c}0.056 \\
(0.252)\end{array}$ \\
\hline POPULATION & & & & & $\begin{array}{l}-0.872 \\
(0.635)\end{array}$ & & & & & \\
\hline$N F A_{t-1}$ & & & & & & $\begin{array}{l}-0.023^{* *} \\
(0.009)\end{array}$ & & & & \\
\hline HOUSEPRICE & & & & & & & $\begin{array}{l}-0.058 \\
(0.035)\end{array}$ & & $\begin{array}{l}-0.062^{*} \\
(0.034)\end{array}$ & \\
\hline INTEREST & & & & & & & & $\begin{array}{c}0.227^{* *} \\
(0.090)\end{array}$ & & $\begin{array}{c}0.231^{* *} \\
(0.076)\end{array}$ \\
\hline$R^{2}$ (within) & 0.439 & 0.613 & 0.611 & 0.611 & 0.618 & 0.653 & 0.619 & 0.638 & 0.619 & 0.639 \\
\hline Hausman test & $\begin{array}{l}48.620^{* * *} \\
(0.000)\end{array}$ & $\begin{array}{c}30.110^{\text {*** }} \\
(0.000)\end{array}$ & $\begin{array}{l}16.120^{\text {*** }} \\
(0.003)\end{array}$ & $\begin{array}{c}14.300^{* *} \\
(0.014)\end{array}$ & $\begin{array}{c}15.010^{* *} \\
(0.010)\end{array}$ & $\begin{array}{l}38.200^{* * *} \\
(0.000)\end{array}$ & $\begin{array}{l}14.320^{* *} \\
(0.014)\end{array}$ & $\begin{array}{l}27.980^{* * *} \\
(0.000)\end{array}$ & $\begin{array}{c}12.150^{* *} \\
(0.059)\end{array}$ & $\begin{array}{c}25.320^{* *} \\
(0.000)\end{array}$ \\
\hline
\end{tabular}

Table 15: Static fixed effect estimates for current account as a percentage of GDP: baseline models and extensions (Notes: The table reports the coefficients for the respective variables in levels. Robust standard errors clustered at the country level are in parentheses. PULLFACTOR corresponds to flows of bank loans to the domestic non-financial private sector excluding loans for house purchases. PUSHFACTOR corresponds to flows of debt claims of domestic banks on debtors in other euro-area countries. Hausman test reports the chi2 test statistic and the corresponding p-value for systematic differences in coefficients of the random effects estimator vs. the fixed effects estimator. $*, * *$ and $* * *$ denote significance at the $10 \%, 5 \%$ and $1 \%$ levels respectively.) 


\begin{tabular}{|c|c|c|c|c|c|c|c|c|c|c|}
\hline Model & $\begin{array}{c}\text { Reference } \\
\text { model }\end{array}$ & $\begin{array}{c}\text { Baseline } \\
\text { model I }\end{array}$ & $\begin{array}{l}\text { Baseline } \\
\text { model II }\end{array}$ & $\begin{array}{c}\text { Extended } \\
\text { baseline } \\
\text { model I }\end{array}$ & $\begin{array}{c}\text { Extended } \\
\text { baseline } \\
\text { model II }\end{array}$ & $\begin{array}{c}\text { Extended } \\
\text { baseline } \\
\text { model III }\end{array}$ & $\begin{array}{c}\text { Extended } \\
\text { baseline } \\
\text { model IV }\end{array}$ & $\begin{array}{c}\text { Extended } \\
\text { baseline } \\
\text { model V }\end{array}$ & $\begin{array}{l}\text { Best fit } \\
\text { model I }\end{array}$ & $\begin{array}{l}\text { Best fit } \\
\text { model II }\end{array}$ \\
\hline RELATIVEGDP & $\begin{array}{l}-0.175^{*} \\
(0.094)\end{array}$ & $\begin{array}{c}0.025 \\
(0.062)\end{array}$ & & & & & & & & \\
\hline$R E A L E X R U L C$ & $\begin{array}{l}-0.268^{* * *} \\
(0.084)\end{array}$ & $\begin{array}{l}-0.132 \\
(0.090)\end{array}$ & $\begin{array}{l}-0.131 \\
(0.092)\end{array}$ & $\begin{array}{l}-0.127 \\
(0.085)\end{array}$ & $\begin{array}{l}-0.108 \\
(0.105)\end{array}$ & $\begin{array}{l}-0.197^{* *} \\
(0.087)\end{array}$ & $\begin{array}{l}-0.213^{* *} \\
(0.080)\end{array}$ & $\begin{array}{l}-0.148 \\
(0.087)\end{array}$ & $\begin{array}{l}-0.201 \\
(0.042)\end{array}$ & $\begin{array}{l}-0.143^{*} \\
(0.079)\end{array}$ \\
\hline GOVBALANCE & $\begin{array}{l}-0.284^{* *} \\
(0.109)\end{array}$ & $\begin{array}{l}0.463^{* * *} \\
(0.143)\end{array}$ & $\begin{array}{l}0.451^{* *} \\
(0.151)\end{array}$ & $\begin{array}{c}0.456^{* *} \\
(0.153)\end{array}$ & $\begin{array}{c}0.451^{* *} \\
(0.154)\end{array}$ & $\begin{array}{l}0.363^{* * *} \\
(0.111)\end{array}$ & $\begin{array}{l}0.469^{* * *} \\
(0.139)\end{array}$ & $\begin{array}{l}0.395^{* *} \\
(0.137)\end{array}$ & $\begin{array}{l}0.502^{* * *} \\
(0.093)\end{array}$ & $\begin{array}{c}0.400^{* *} \\
(0.139)\end{array}$ \\
\hline PULLF ACTOR & & $\begin{array}{l}-0.705^{* * *} \\
(0.101)\end{array}$ & $\begin{array}{l}-0.688^{* * *} \\
(0.120)\end{array}$ & $\begin{array}{l}-0.668^{* * *} \\
(0.134)\end{array}$ & $\begin{array}{l}-0.635^{* * *} \\
(0.111)\end{array}$ & $\begin{array}{l}-0.562^{* * *} \\
(0.123)\end{array}$ & $\begin{array}{l}-0.566^{* * *} \\
(0.119)\end{array}$ & $\begin{array}{l}-0.550^{* * *} \\
(0.087)\end{array}$ & $\begin{array}{l}-0.584^{* * *} \\
(0.074)\end{array}$ & $\begin{array}{l}-0.517^{* * *} \\
(0.107)\end{array}$ \\
\hline PUSHFACTOR & & $\begin{array}{l}-0.033 \\
(0.069)\end{array}$ & $\begin{array}{l}-0.031 \\
(0.067)\end{array}$ & $\begin{array}{l}-0.032 \\
(0.065)\end{array}$ & $\begin{array}{l}-0.031 \\
(0.061)\end{array}$ & $\begin{array}{l}-0.023 \\
(0.043)\end{array}$ & $\begin{array}{c}0.001 \\
(0.057)\end{array}$ & $\begin{array}{l}-0.039 \\
(0.058)\end{array}$ & $\begin{array}{c}0.000 \\
(0.036)\end{array}$ & $\begin{array}{l}-0.040 \\
(0.056)\end{array}$ \\
\hline$D E P E N D E N C Y$ & & & & $\begin{array}{c}0.169 \\
(0.287)\end{array}$ & & & & & $\begin{array}{c}0.051 \\
(0.135)\end{array}$ & $\begin{array}{c}0.231 \\
(0.283)\end{array}$ \\
\hline POPULATION & & & & & $\begin{array}{l}-0.957 \\
(0.557)\end{array}$ & & & & & \\
\hline$N F A_{t-1}$ & & & & & & $\begin{array}{l}-0.027^{* * *} \\
(0.008)\end{array}$ & & & & \\
\hline HOUSEPRICE & & & & & & & $\begin{array}{l}-0.196^{* *} \\
(0.066)\end{array}$ & & $\begin{array}{l}-0.190^{* * *} \\
(0.048)\end{array}$ & \\
\hline INTEREST & & & & & & & & $\begin{array}{l}0.431^{* * *} \\
(0.114)\end{array}$ & & $\begin{array}{l}0.448^{* * *} \\
(0.092)\end{array}$ \\
\hline$R^{2}$ (within) & 0.311 & 0.569 & 0.568 & 0.573 & 0.575 & 0.621 & 0.618 & 0.623 & 0.618 & 0.631 \\
\hline Hausman test & $\begin{array}{l}44.560^{* * *} \\
(0.000)\end{array}$ & $\begin{array}{l}16.900^{* * *} \\
(0.005)\end{array}$ & $\begin{array}{c}10.720^{* *} \\
(0.030)\end{array}$ & $\begin{array}{c}9.500^{*} \\
(0.091)\end{array}$ & $\begin{array}{c}9.980^{* *} \\
(0.076)\end{array}$ & $\begin{array}{c}30.670^{* * *} \\
(0.000)\end{array}$ & $\begin{array}{c}9.600^{*} \\
(0.087)\end{array}$ & $\begin{array}{l}22.360^{* * *} \\
(0.000)\end{array}$ & $\begin{array}{c}8.030 \\
(0.236)\end{array}$ & $\begin{array}{c}21.720^{* * *} \\
(0.001)\end{array}$ \\
\hline
\end{tabular}

Table 16: Static fixed effect estimates for current account as a percentage of GDP: baseline models and extensions using instrumented variables (Notes: The table reports the coefficients for the respective variables in levels. Robust standard errors clustered at the country level are in parentheses. Variables are instrumented by their own first lag. PULLFACTOR corresponds to flows of bank loans to the domestic non-financial private sector excluding loans for house purchase. PUSHFACTOR corresponds to flows of debt claims of domestic banks on debtors in other euro-area countries. Hausman test reports the chi2 test statistic and the corresponding p-value for systematic differences in coefficients of the random effects estimator vs. the fixed effects estimator. $*, * *$ and $* * *$ denote significance at the $10 \%, 5 \%$ and $1 \%$ levels respectively.) 


\section{References}

Abad, J., A. Löffler, G. Schnabl, and H. Zemanek (2013). Fiscal divergence, current account and TARGET2 imbalances in the EMU. Intereconomics 48(1), 51-58.

Ahrend, R. (2010). Monetary ease: A factor behind financial crises? Some evidence from OECD countries. Economics - The Open-Access, Open-Assessment E-Journal 4, 1-30.

Aizenman, J. and Y. Jinjarak (2009, September). Current account patterns and national real estate markets. Journal of Urban Economics 66(2), 75-89.

Arghyrou, M. G. and G. Chortareas (2008, 09). Current Account Imbalances and Real Exchange Rates in the Euro Area. Review of International Economics 16(4), 747-764.

Barnes, S., J. Lawson, and A. Radziwill (2010, December). Current Account Imbalances in the Euro Area: A Comparative Perspective. OECD Economics Department Working Papers 826, OECD Publishing.

Belke, A. and C. Dreger (2013, 02). Current Account Imbalances in the Euro Area: Does Catching up Explain the Development? Review of International Economics 21(1), 6-17.

Blackburne III, E. F. and M. W. Frank (2007, September). XTPMG: Stata module for estimation of nonstationary heterogeneous panels. Statistical Software Components, Boston College Department of Economics.

Blanchard, O. and F. Giavazzi (2002). Current Account Deficits in the Euro Area: The End of the Feldstein Horioka Puzzle? Brookings Papers on Economic Activity 33(2), $147-210$.

Borio, C. and P. Disyatat (2010, 09). Unconventional Monetary Policies: An Appraisal. Manchester School 78(1), 53-89.

Borio, C. and P. Disyatat (2011, May). Global imbalances and the financial crisis: Link or no link? BIS Working Papers (346).

Brzoza-Brzezina, M., M. Kolasa, and K. Makarski (2015). Macroprudential policy and imbalances in the euro area. Journal of International Money and Finance 51(C), 137154.

Campa, J. M. and A. Gavilan (2011, February). Current accounts in the euro area: An intertemporal approach. Journal of International Money and Finance 30(1), 205-228.

CaZorzi, M., A. Chudik, and A. Dieppe (2012). Thousands of models, one story: Current account imbalances in the global economy. Journal of International Money and Finance 31(6), 1319-1338.

Chinn, M. D. and E. S. Prasad (2003, January). Medium-term determinants of current accounts in industrial and developing countries: an empirical exploration. Journal of International Economics 59(1), 47-76. 
Comunale, M. and J. Hessel (2014, October). Current account imbalances in the Euro area: Competitiveness or financial cycle? DNB Working Papers 443, Netherlands Central Bank, Research Department.

Cuestas, J. C. and K. Staehr (2014, October). The great (De)leveraging in the GIIPS countries. Domestic credit and net foreign liabilities 1998 - 2013. Bank of Estonia Working Papers 2014-4, Bank of Estonia.

Disyatat, P. (2011, 06). The Bank Lending Channel Revisited. Journal of Money, Credit and Banking 43(4), 711-734.

European Commission (2012). Current account surpluses in the EU. European Economy 9/2012, Directorate General Economic and Financial Affairs (DG ECFIN), European Commission.

Fratzscher, M., L. Juvenal, and L. Sarno (2010, July). Asset prices, exchange rates and the current account. European Economic Review 54(5), 643-658.

Geiger, F., M. Rupprecht, and J. Muellbauer (2015). The Housing Market, Household Portfolios, and the German Consumer. ECB Working Paper (forthcoming).

Gossé, J.-B. and F. Serranito (2014). Long-run determinants of current accounts in OECD countries: Lessons for intra-European imbalances. Economic Modelling 38(C), 451-462.

Hobza, A. and S. Zeugner (2014). Current accounts and financial flows in the euro area. Journal of International Money and Finance 48(PB), 291-313.

Hristov, N., O. Hülsewig, and T. Wollmershäuser (2012). Loan supply shocks during the financial crisis: Evidence for the Euro area. Journal of International Money and Finance 31(3), 569-592.

Jakab, Z. and M. Kumhof (2015, May). Banks are not intermediaries of loanable funds and why this matters. Bank of England working papers 529, Bank of England.

Kool, C., E. de Regt, and T. van Veen (2013). Money Overhang, Credit Overhang and Financial Imbalances in the Euro Area. CESifo Working Paper Series 4476, CESifo Group Munich.

Kuzin, V. and F. Schobert (2015). Why does bank credit not drive money in Germany (any more)? Economic Modelling 48(C), 41-51.

Lane, P. R. (2013, April). Capital Flows in the Euro Area. European Economy - Economic Papers 497, Directorate General Economic and Financial Affairs (DG ECFIN), European Commission.

Lane, P. R. and P. McQuade (2014). Domestic Credit Growth and International Capital Flows. Scandinavian Journal of Economics 116(1), 218-252.

Lane, P. R. and G. M. Milesi-Ferretti (2012). External adjustment and the global crisis. Journal of International Economics 88(2), 252-265. 
McLeay, M., A. Radia, and R. Thomas (2014, Mar). Money creation in the modern economy. Bank of England Quarterly Bulletin.

Moore, B. (1988). Horizontalists and Verticalists: The Macroeconomics of Credit Money. Cambridge University Press.

Pesaran, H. and A. Chudik (2013, May). Common Correlated Effects Estimation of Heterogeneous Dynamic Panel Data Models with Weakly Exogenous Regressors. Cambridge Working Papers in Economics 1317, Faculty of Economics, University of Cambridge.

Pesaran, M. H. (2006, 07). Estimation and Inference in Large Heterogeneous Panels with a Multifactor Error Structure. Econometrica 74(4), 967-1012.

Pesaran, M. H., Y. Shin, and R. P. Smith (1999). Pooled mean group estimation of dynamic heterogeneous panels. Journal of the American Statistical Association 94, 621-634.

Pesaran, M. H. and R. Smith (1995, July). Estimating long-run relationships from dynamic heterogeneous panels. Journal of Econometrics 68(1), 79-113.

Polito, V. and M. Wickens (2014). How the Euro Crisis Evolved and how to Avoid Another: EMU, Fiscal Policy and Credit Ratings. Journal of Macroeconomics 39, $364-374$.

Schmitz, B. and J. von Hagen (2011). Current account imbalances and financial integration in the euro area. Journal of International Money and Finance 30(8), 1676-1695.

Schnabl, G. and T. Wollmershäuser (2013). Fiscal Divergence and Current Account Imbalances in Europe. CESifo Working Paper Series (4108).

Schoder, C., C. R. Proano, and W. Semmler (2013, November). Are The Current Account Imbalances Between Emu Countries Sustainable? Evidence From Parametric And NonParametric Tests. Journal of Applied Econometrics 28(7), 1179-1204.

Sinn, H.-W. and T. Wollmershäuser (2012, August). Target loans, current account balances and capital flows: the ECB's rescue facility. International Tax and Public Finance 19(4), 468-508.

Smith, C. E. (2011, October). External balance adjustment: An intra-national and international comparison. Journal of International Money and Finance 30(6), 1195-1213.

Spiegel, M. M. (2009, 09). Monetary and Financial Integration in the EMU: Push or Pull? Review of International Economics 17(4), 751-776.

Walters, A. (1990). Sterling in Danger - The Economic Consequences of Pegged Exchange Rates. Fontana/Collins.

Werner, R. A. (1997). Towards a new monetary paradigm: a quantity theorem of disaggregated credit, with evidence from Japan. Kredit und Kapital 30(2), 276-309. 
Wyplosz, C. (2013, October). The Eurozone Crisis and the Competitiveness Legend. Asian Economic Papers 12(3), 63-81.

Zwick, L. (2015). International liquidity shocks and domestic loan supply in the euro area. Ruhr Economic Papers 564, Rheinisch-Westfälisches Institut für Wirtschaftsforschung (RWI), Ruhr-University Bochum, TU Dortmund University, University of DuisburgEssen. 